\title{
Human Coronaviruses: Genetics, Virulence Factors and Pathophysiology, Diseases' Epidemiology
}

\author{
Gnatoulma Katawa $^{* 1}$, Banfitebiyi Gambogou ${ }^{1,2}$, Christèle T. Nguepou ${ }^{1}$, Essoham Ataba ${ }^{1}$, Manuel Ritter ${ }^{3}$, \\ Eya H. Kamassa ${ }^{1}$, Fagdéba D. Bara ${ }^{1}$, Simplice D. Karou ${ }^{1}$, Yaovi Ameyapoh ${ }^{1}$ \\ ${ }^{1}$ Advanced School of Biological and Food Techniques (ESTBA) / Laboratory of Microbiology and Food Quality \\ Control / Research Unit in Immunology and Immunomodulation (UR2IM), University of Lomé, Togo \\ ${ }^{2}$ Togolese Institute for Agronomic Research (ITRA), Togo \\ ${ }^{3}$ Institute for Medical Microbiology, Immunology and Parasitology (IMMIP), University Hospital Bonn (UKB), Bonn, \\ Germany
}

*Corresponding author: Gnatoulma KATAWA; mahkatawa @ yahoo.fr

Received 13 September 2021;

Accepted 30 September 2021;

Published 08 October 2021

\begin{abstract}
Coronaviruses are pathogens for both animals and humans. The recent Coronavirus Disease (Covid-19), caused by a novel Coronavirus (SARSCoV-2), outbreak that took place in Hubei (Wuhan, China) from December 2019 aroused numerous questions regarding the nature and the origin of the SARS-CoV-2. Literature review of the main publications from scientific data bases was undertaken. These data revealed similarities of symptoms and identity of genome with the SARS-CoV. In this review, the genetics and virulence factors of coronaviruses, the disease pathophysiology and epidemiology were examined.
\end{abstract}

Keywords: Pathophysiology, epidemiology, coronavirus diseases, genome, SARS-CoV

\section{Introduction}

Humanity has been struggling against pathogens. Theses pathogens cause parasitic diseases ${ }^{[1]}$, bacterial infections and viral such us HIV ${ }^{[2]}$, hepatitis $\mathrm{B}^{[3,4]}$ and recent Covid-19 causes by SARS-CoV$2^{[5]}$. Coronaviridae are single-stranded, positive-sense RNA viruses enveloped non-segmented, designated after their corona or crown-like on electron microscopy ${ }^{[6,7]}$. The International Committee on Taxonomy of Viruses (ICTV) established in 1975 the family of Coronavirus, which was divided into two genera in April 1992: the coronavirus genus and the torovirus genus ${ }^{[8]}$. Three genetically and serogically groups of coronavirus genus have been described ${ }^{[9]}$. Group I comprise Human CoV-229E (HCoV-229E), Human CoV-NL63 (HCoV-NL63) and Feline infectious peritonitis virus (FIPV). Group II includes Human CoVOC43 (HCoV-OC43), Human CoV-HKU1 (HCoV-KHU1), Severe acute respiratory syndrome-CoV(SARS-CoV) and Mouse hepatitis virus (MHV). The group III contains bronchitis Infectious virus (IBV) ${ }^{[9-11]}$. The viral taxonomy has been regularly reviewed according to the following orders: the order of Nidovirales, created in 1996, which currently groups together three families (Coronaviridae, Arteriviridae and Roniviridae). These viruses have in common the organization of the RNA genome and the replication strategy but differ in their morphology, their capsid structure and the size of their genome which ranges from 13000 nucleotides for arterivirus to 31000 nucleotides for coronavirus ${ }^{[12]}$. Thus, group I and II coronaviruses infect mammals, including humans and group III coronaviruses are a group of avian viruses [13].

The classification of SARS-CoV has been much debated and the various phylogenetic analyzes proposed either to place it in a fourth group, or in a group II "extended". Finally, the latter solution was adopted and currently subdivided group II into $2 \mathrm{a}$ and $2 \mathrm{~b}$, and includes SARS-CoV as well as all the "SARS-CoV-like" or SL-CoV virus described in the different animal species ${ }^{[14,15]}$. In the 1960s, Human $\mathrm{CoV}(\mathrm{HCoV})$ comprised six strains: 229E, OC43 are most known than B814, OC16, OC37 and OC48. In 2003, the Chinese population was infected with a virus causing severe acute respiratory syndrome (SARS) in Guangdong province.

The virus was confirmed as a member of the Beta coronavirus subgroup and was named SARS-CoV ${ }^{[16]}$. On the thirteenth June, 2012, the first reported case of Middle East respiratory syndrome coronavirus (MERS-CoV) occurred in Jeddah, Saudi Arabia and caused an endemic in Middle Eastern countries. At the end of 2019, a novel coronavirus was discovered at Wuhan in China ${ }^{[17,18]}$. This virus was reported to be a member of the group $2 \mathrm{~b}$ coronaviruses ${ }^{[19]}$. 
The ICTV named the virus as SARS-CoV-2 due to it's genetic similarity to SARS and the disease was named Covid-19 because of the year of the outbreak ${ }^{[20]}$. In total nine $\mathrm{HCoV}$ strains are now identified: 229E, OC43, B814, OC16, OC37 and OC48, SARS-CoV, MERS and SARS-CoV-2 [21]. HCoV-229E was isolated in 1966 from human embryonic kidney cells and has been adapted to several types of cells, including MRC5, cells widely used in virology laboratories. HCoV-OC43 was isolated in 1967 on culture of trachea after passages on mice brains to the line HRT18 (human rectal carcinoma). HCoV-NL63 (strain Amsterdam 1) was isolated in 2004 from the LLC-MK2 line and SARS-CoV on Vero E6 cells ${ }^{[22]}$. Only HCoV-HKU1 to date has never been isolated in cell culture but it has been characterized by molecular biology. It is important to note that apart from the prototype strains, the coronavirus remain very difficult to cultivate and there are few isolates ${ }^{[23]}$. Finally, it is important to remember that these viruses are class 2 agents except the three SARS-CoV, which require a level 3 containment laboratory for their handling. This literature review from main publications presents the genetics, the virulence factors, the etiology, epidemiology and pathophysiology of coronavirus diseases.

\section{Methodology}

Protocol: A systematic review of the published literature was undertaken from PubMed, Elsevier, Google scholar, HINARI, WHO, ECDC, and NCBI databases, in accordance with the preferred reporting elements for systematic reviews. Our initial objective was to carry out a systematic analysis and a metaanalysis to identify the relevant articles reporting on coronaviruses in order to analyze the genetics factors as responsible for virulence factors, epidemiology and pathophysiology of coronavirus diseases. However, the evaluation of the published studies was done using Endnote version X9 (Thomson Reuters) and it showed that the published papers related to the impact of coronaviruses on social and economic life or not answer the research question were excluded. All the literature found were discussed by the editorial team of this paper. Some articles have been included from others. The process of literature review is shown on Figure 1.

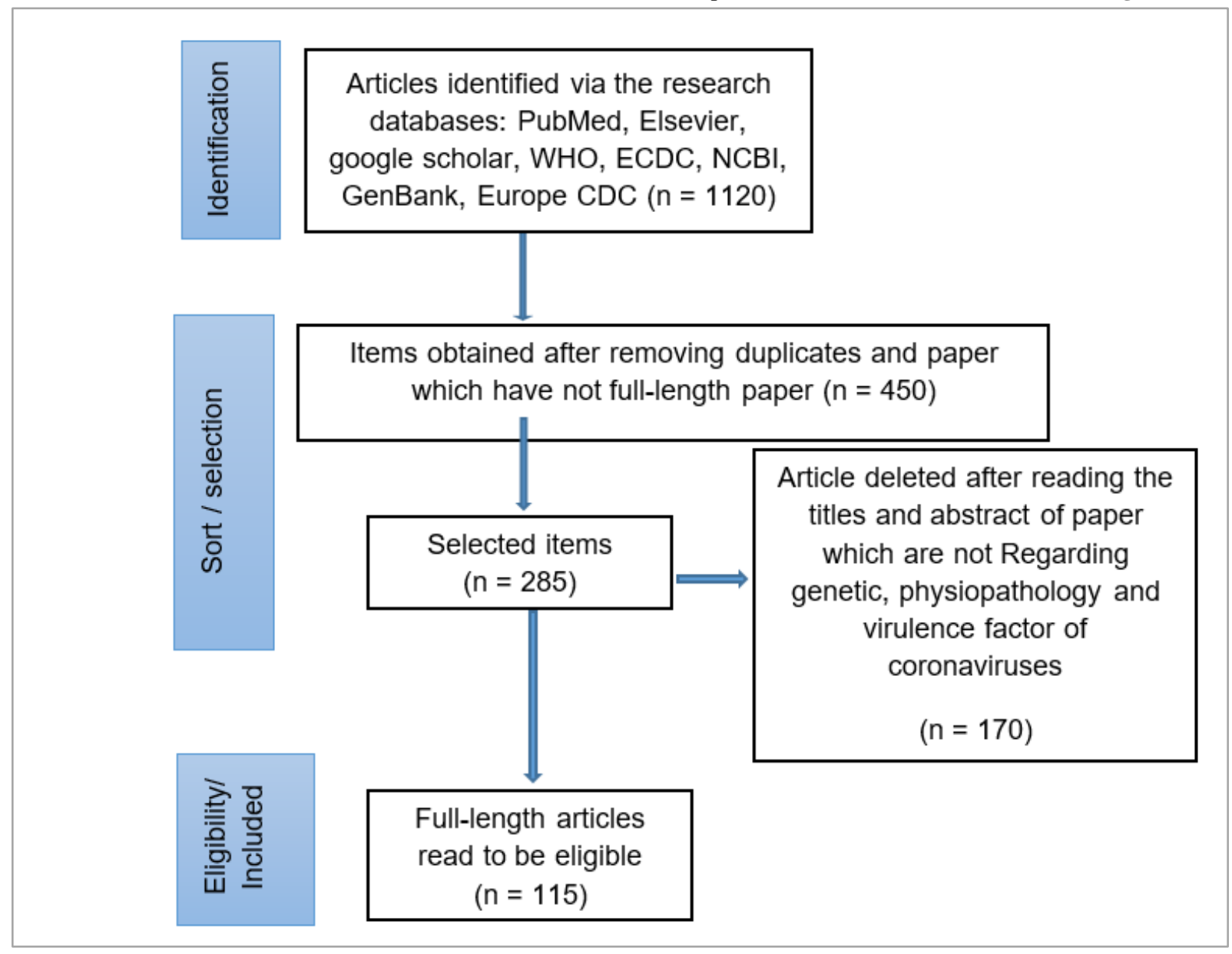

Figure 1: Process of data collection.

Data analysis: The extracted data were used for descriptive statistical analyzes. Further analysis was carried out in several stages. The Meta-analyzes as the gene fragments alignment, the phylogenetic tree construction, the identification of protein or gene similarities were performed with Blast, tBlast and Mega X v10.1.8. The cartographic representing full length genome sequence were done by Excel.

The collected data/information were classified into different groups: genome variability, virulence factor, physiopathology and epidemiology of human coronaviruses.

\section{Genome similarity and conserved regions}

$\underline{\text { www.ijirms.in }}$
The figure 2, 3, 4 and 5 represent the genome of Coronaviridae, the phylogenetic tree of coronaviridae, and the Human coronaviruses. The analysis of 33 full length publication papers and data GenBank analysis of all coronaviridae genome sequences and records how that coronaviruses' genome is a linear, nonsegmented single stranded, positive-sense RNA, directly infectious RNA molecule. The main characteristic of this virus is the size of its genome, which is the largest known viral RNA (27000 to 30 000 nucleotides). The genomic organization is conserved among all coronavirus species and approximately 20000 nucleotides (nt) consist of two open reading frames ORF1a and ORF1b over lapping and encoding two protein precursors which are cleaved

whwinims.in 
into 15 to 16 fragments and form the replication complex (Figure

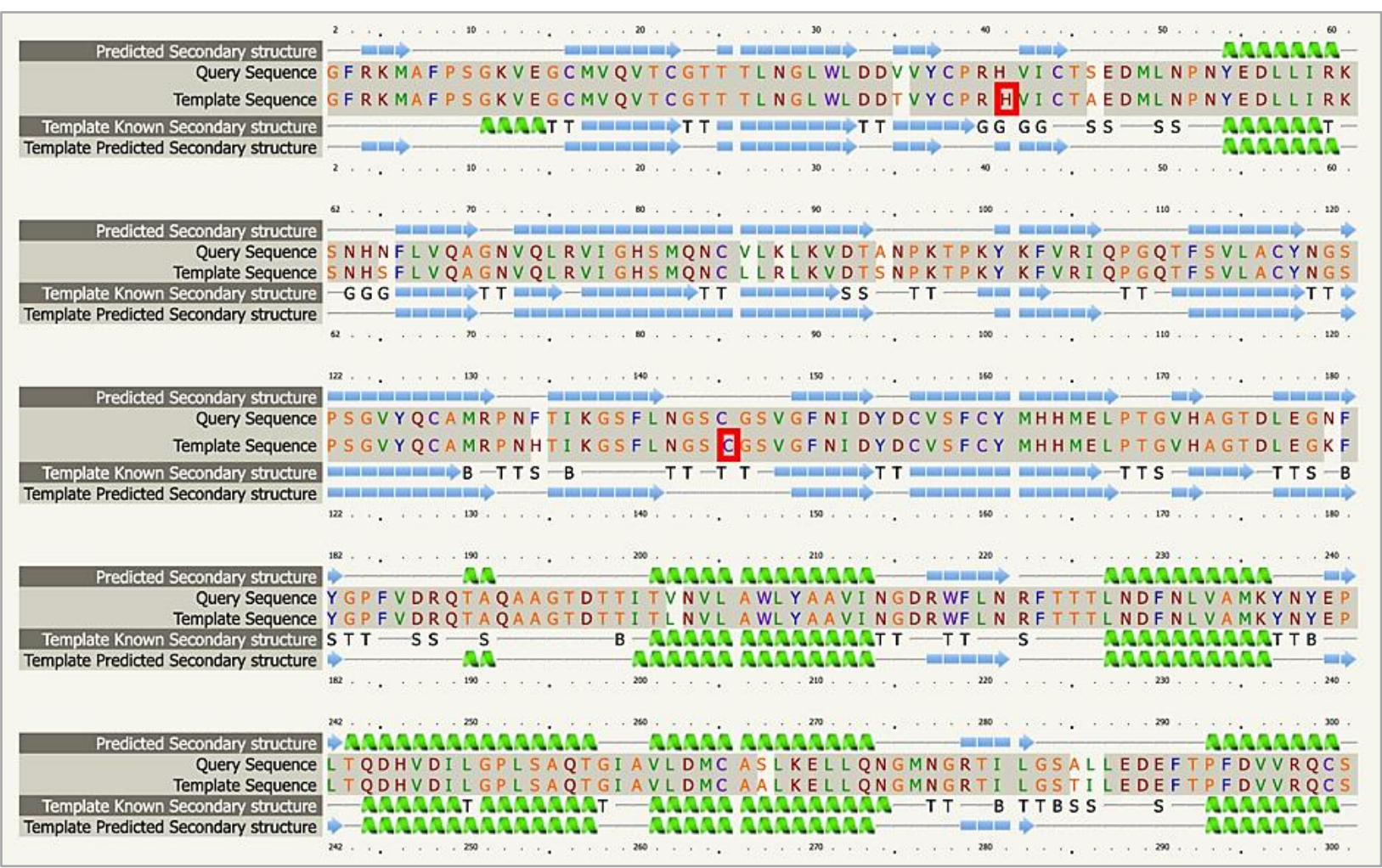

Figure 2: structure of coronaviridae genome (SARS-CoV 2) (Innophore technology).

The other conserved regions consist of four to five genes (HE-S-E$\mathrm{M}-\mathrm{N}$ ) in a precise and conserved order and which encode the structural proteins. The figure 3 shows the phylogenic repartition among the human coronaviruses ( $\mathrm{HCoV})$ and show that the genome of the SARS-CoV-2 is mostly alike the previous human coronavirus (SARS-like bat $\mathrm{CoV}$ ). Coronaviruses belong to Coronaviridae familly and fall into four distinct genera such us alphacoronavirus (1a, 1b) (blue), betacoronavirus (2a, 2b, 2c, 2d) (pink), deltacoronavirus (light green) and gamma coronavirus (deep green ${ }^{[24,25]}$. This tree is adapted from the published trees of
Coronavirinae ${ }^{[26]}$ wich was reconstructed with sequences of the complete RNA- dependent RNA polymerase-coding region of the representative novel coronaviruses (maximum likelihood method using MEGA 7.2 software). Severe Acute respiratory syndrome coronavirus (SARS-CoV); SARS- related coronavirus (SARSr$\mathrm{CoV}$ ); the Middle east respiratory syndrome coronavirus (MERS$\mathrm{CoV})$; Porcine entericdiarrhea virus (PEDV); Wuhan seafood market pneumonia (Wuhan-Hu-1). Bat CoV RaTG13 Showed high sequence identity to SARS-CoV-2 ${ }^{[27]}$.

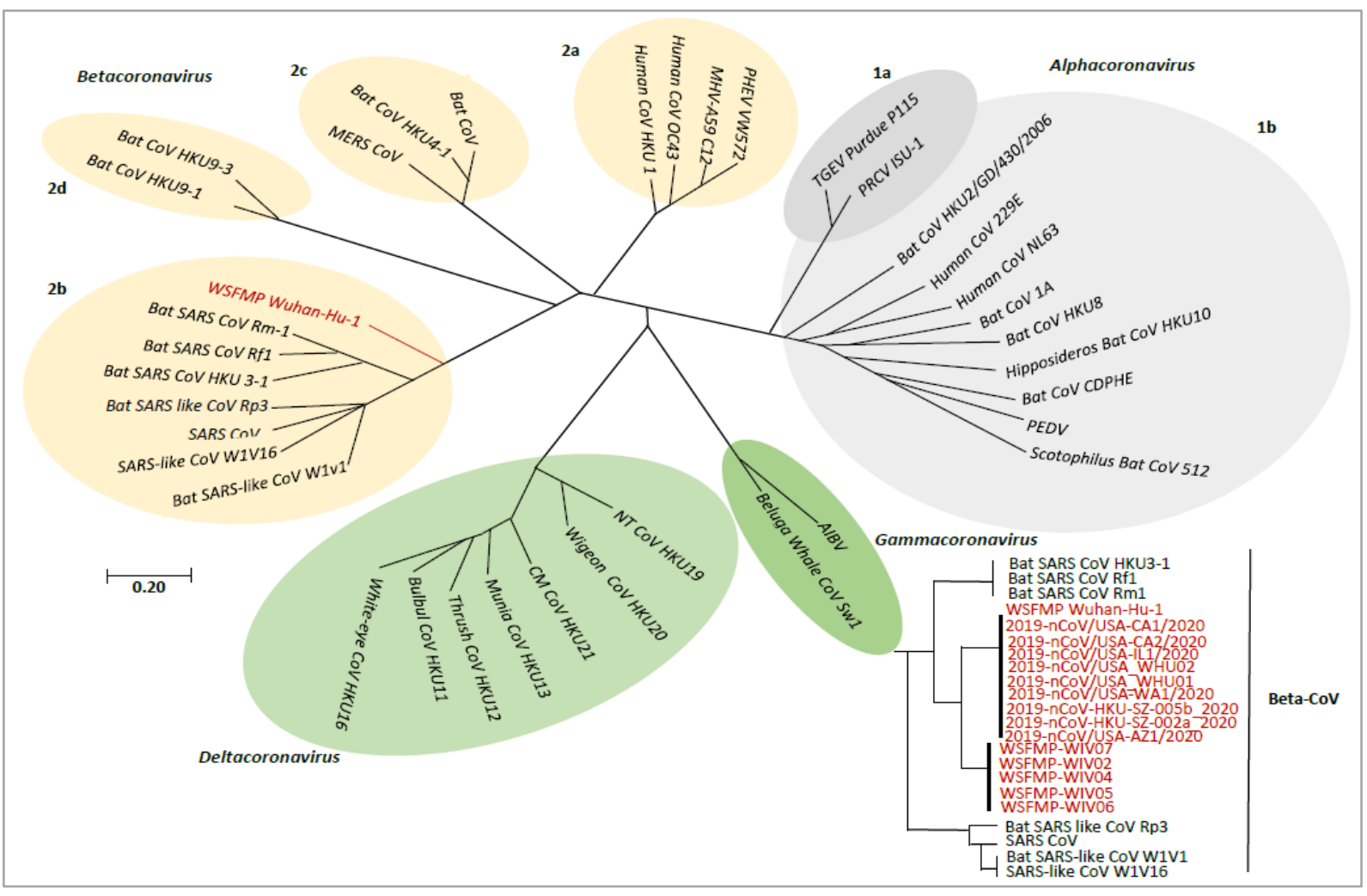


Figure 3: Evolutionary repartition of Coronaviridae (Adapted form ${ }^{114}$ )

Figure 4 shows the evolutionary relation among the human coronaviruses $(\mathrm{HCoV})$. The novel acute respiratory syndrome coronavirus 2 (SARS-CoV-2) is a new coronavirus that emerged through recombination of bat SARS-relatedcoronaviruses (SARSr$\mathrm{CoVs}$ ) with infected civets and humans and adapted to these hosts and became pandemic ${ }^{[8]}$. Middle east respiratory syndrome coronavirus (MERS-CoV) likely spilled over from bats to dromedary. HCoV-NL63 and HCoV-229E usually cause mild infections in immunocompetent humans ${ }^{[13]}$. HKU1 and $\mathrm{HCoV}$ OC43 are alsomost harmless in humans ${ }^{[28]}$. The coronaviruses infecting humans $(\mathrm{HCoVs})$ belong to alpha and beta coronaviruses genera. The alpha coronaviruses infecting humans are HCoV-229E and $\mathrm{HCoV}$ NL63, and the beta coronaviruses infecting humans are HCoV-HKU1, HCoV-OC43 (Figure 4). The Middle east respiratory syndrome coronavirus (MERS-CoV), SARS-CoV and SARS-CoV-2 are betacoronaviruses ${ }^{[29]}$.

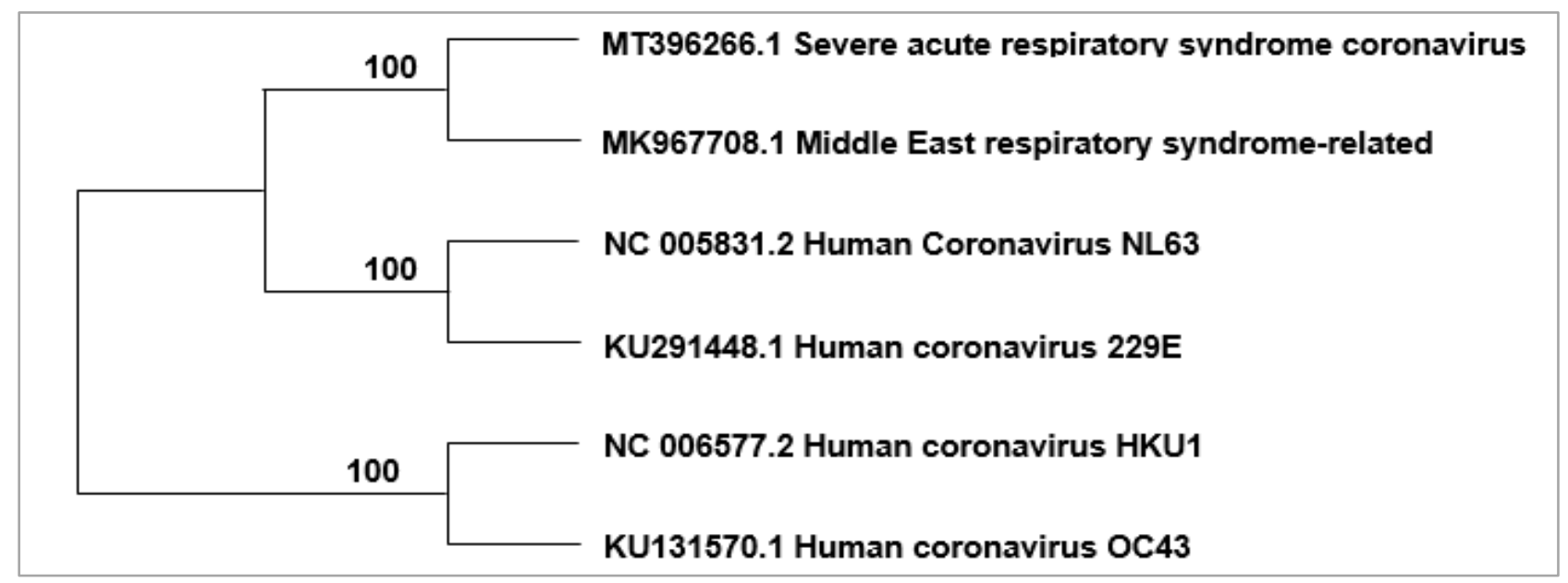

Figure 4: Evolutionary relationships of taxa of Human coronaviruses ${ }^{103}$

\section{Coronavirus virulence factors}

Figures 5 and 6 represent respectively the coronavirus structures, the host spectrum, the virulence factors similarity among $\mathrm{HCoV}$ and host factors. 6A show the similarity of Protein E, while 6B, 6C and $6 \mathrm{D}$ relate accordingly the similarity of Protein $\mathrm{M}$, Protein $\mathrm{S}$, and Protein N. Coronaviruses are enveloped pleomorphic viruses of 60 to $200 \mathrm{~nm}$ in diameter. The appearance in a crown visible by electron microscopy is due to the presence on the viral envelope of spicules in the shape of a club $20 \mathrm{~nm}$ high and made up of the

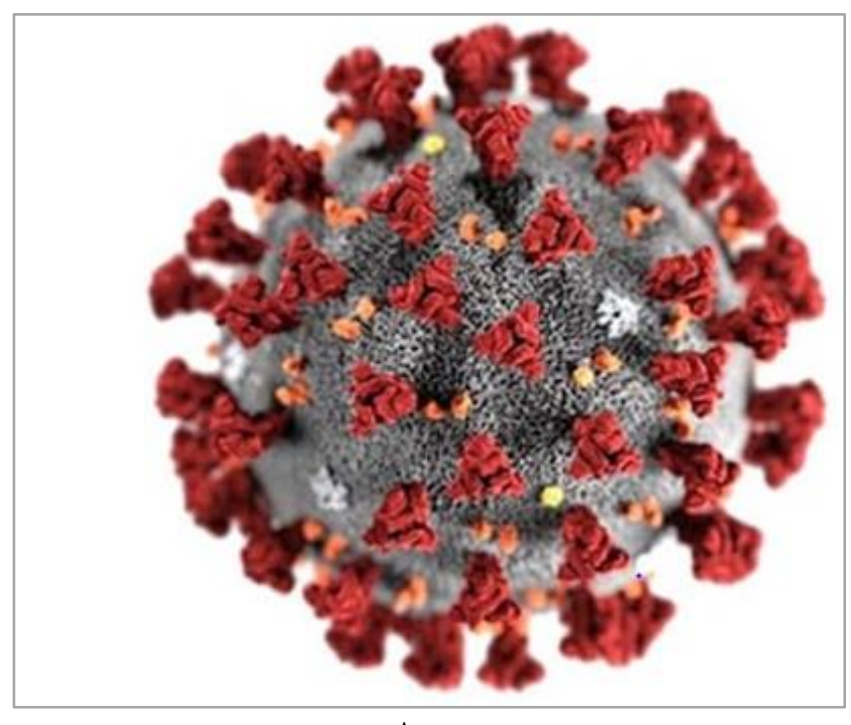

A surface protein $\mathrm{S}$. The other envelope glycoproteins are the protein $\mathrm{M}$, protein $\mathrm{E}$ and for group 2 coronavirus, hemagglutinin esterase (HE). The viral capsid is helical symmetry; it consists of the protein N, which is closely linked to genomic RNA. Protein S is a type I membrane glycoprotein, and plays a key role in the first stages of the viral cycle. It is responsible for the attachment of the virus to the target cell by its S1 subunit and largely determines the tissue tropism of the virus and its host spectrum. It is also responsible for the membrane fusion by its S2 subunit. In addition, it is the main target of the cellular and humoral immune response and induces the formation of neutralizing antibodies ${ }^{[29-34]}$.

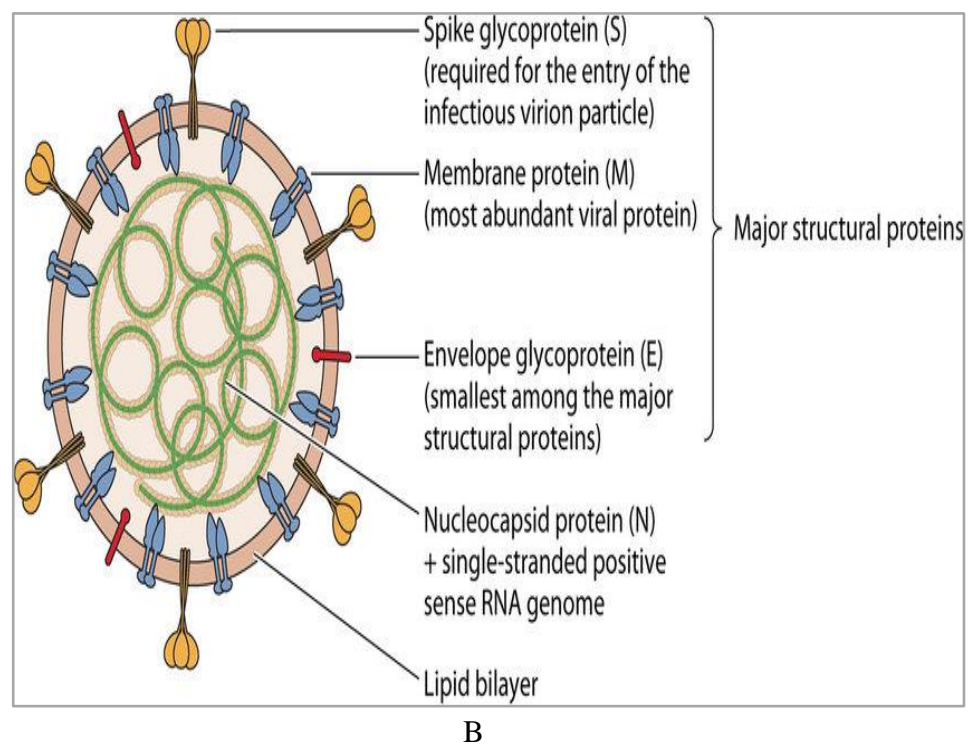

Figure 5: Structure of Coronaviridae (National Institute of Allergy and Infectious Diseases (NIAID), 2020. A: coronaviruses view in electronic microscope; B: structure of coronaviruses. 


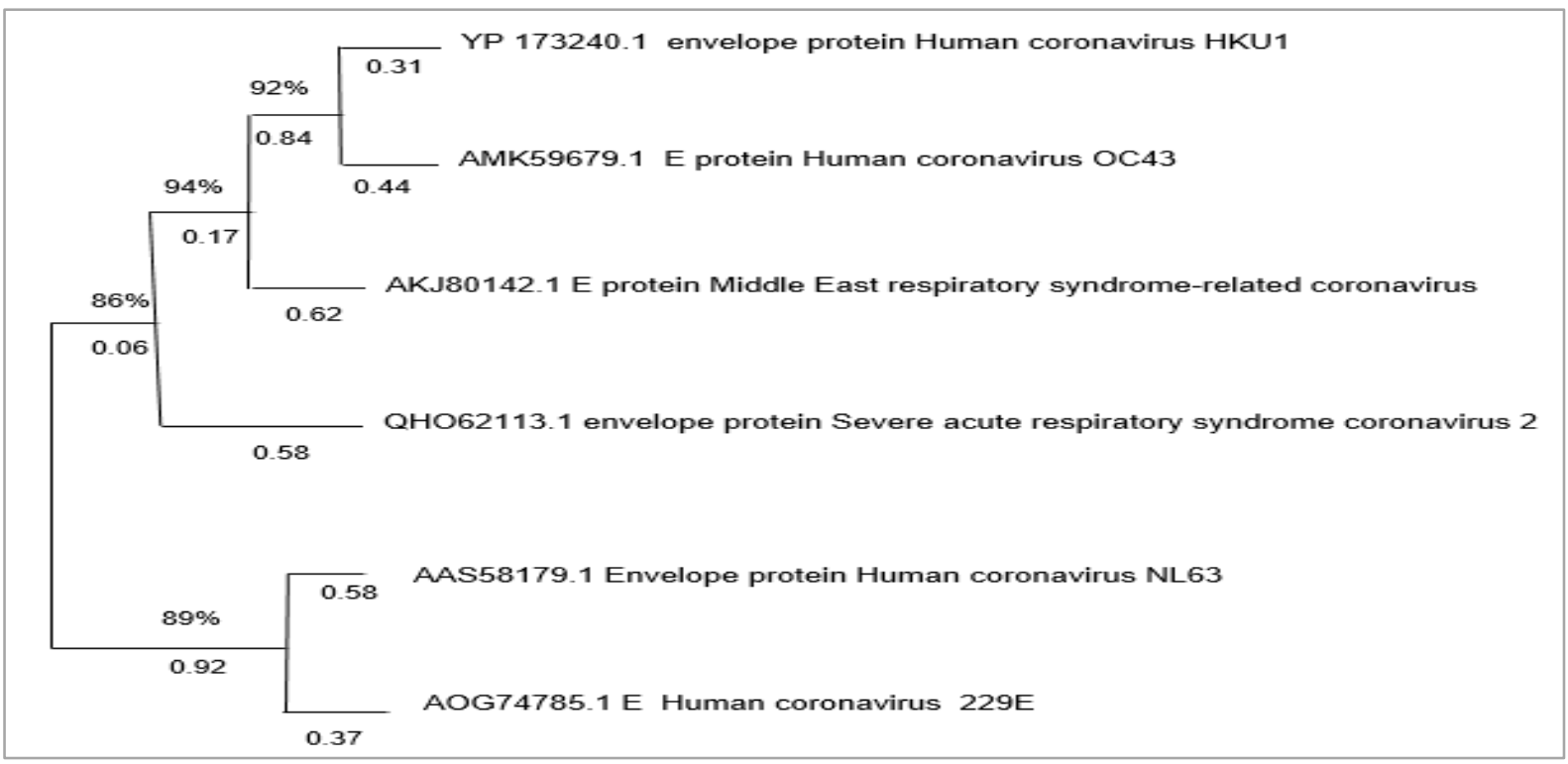

(A)

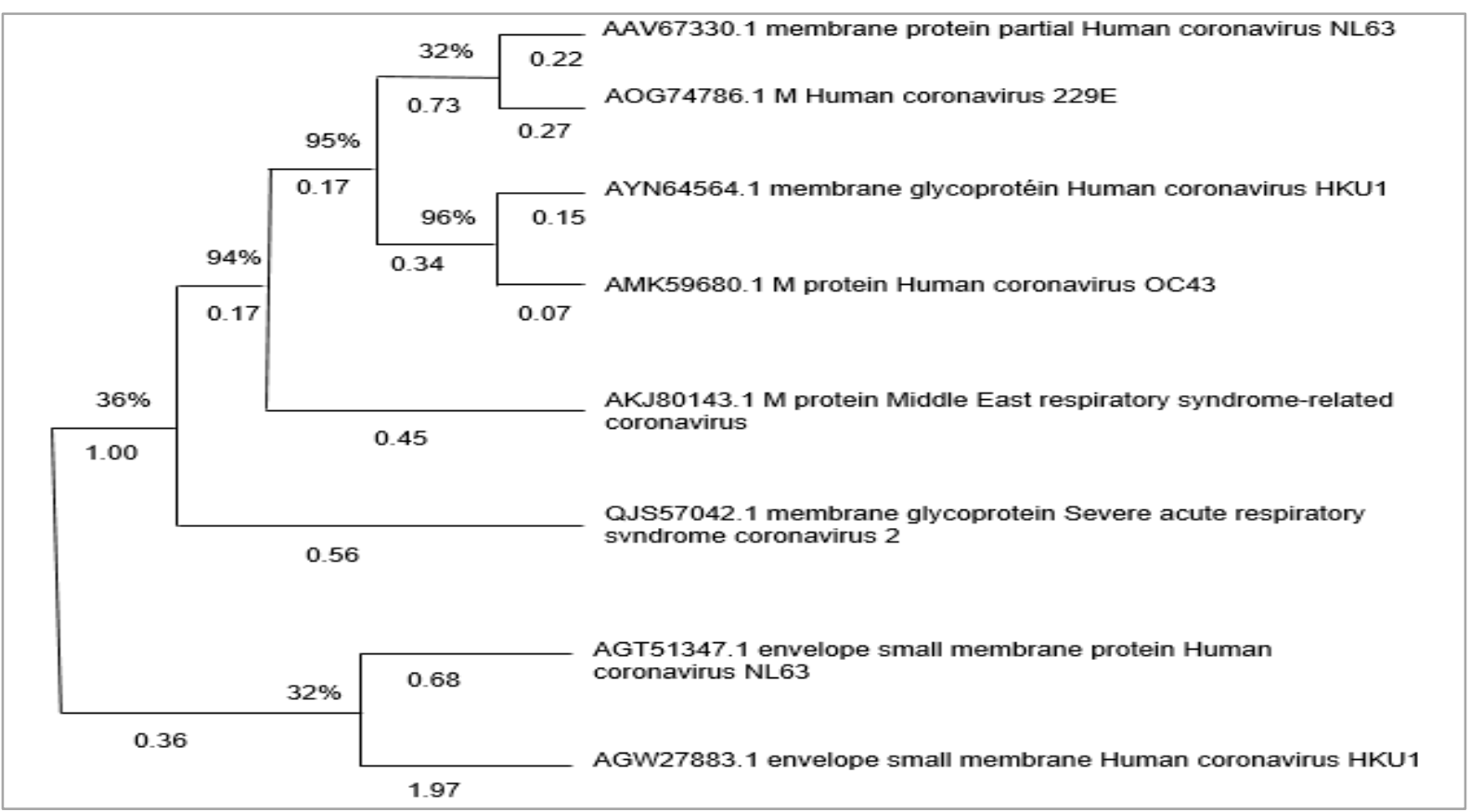

(B)

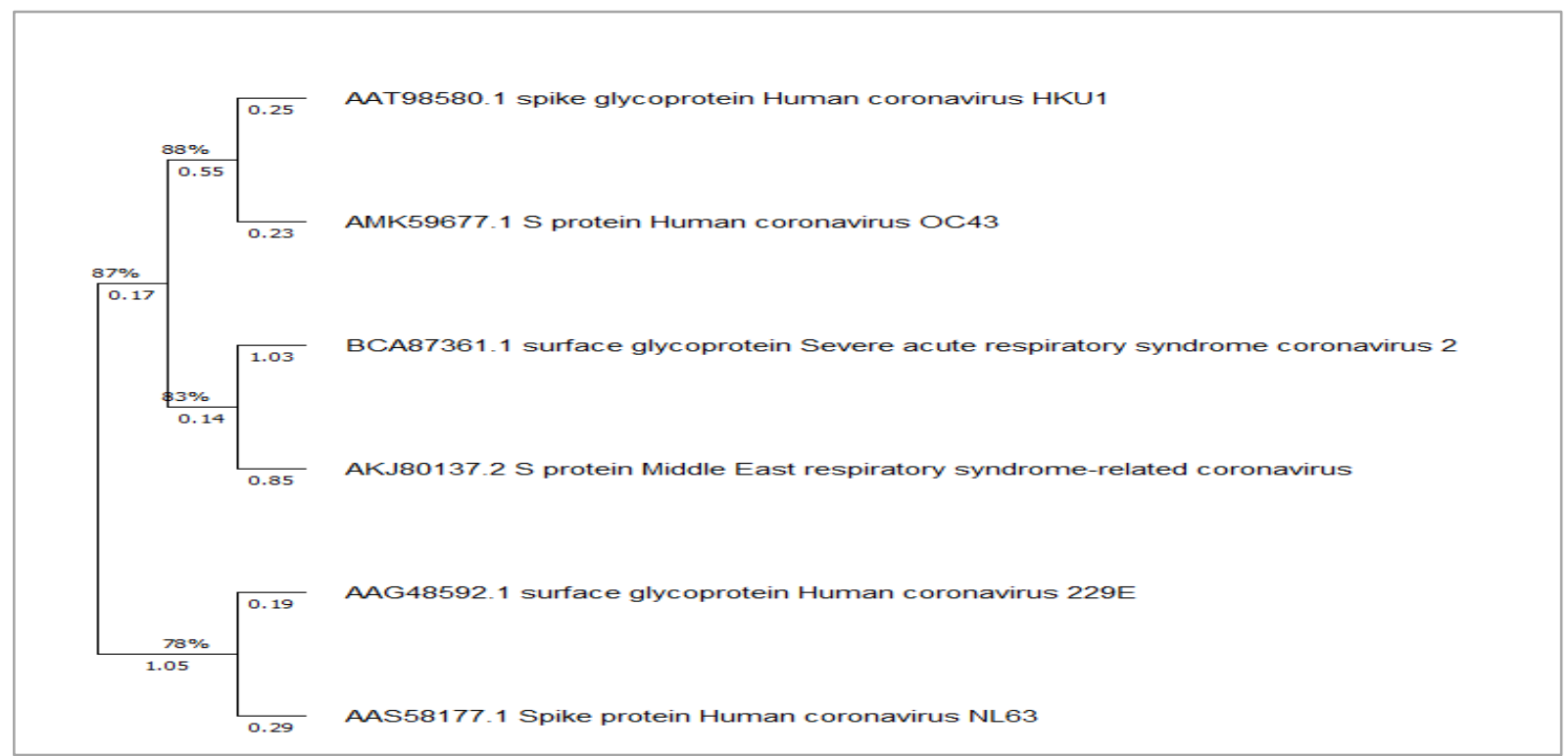




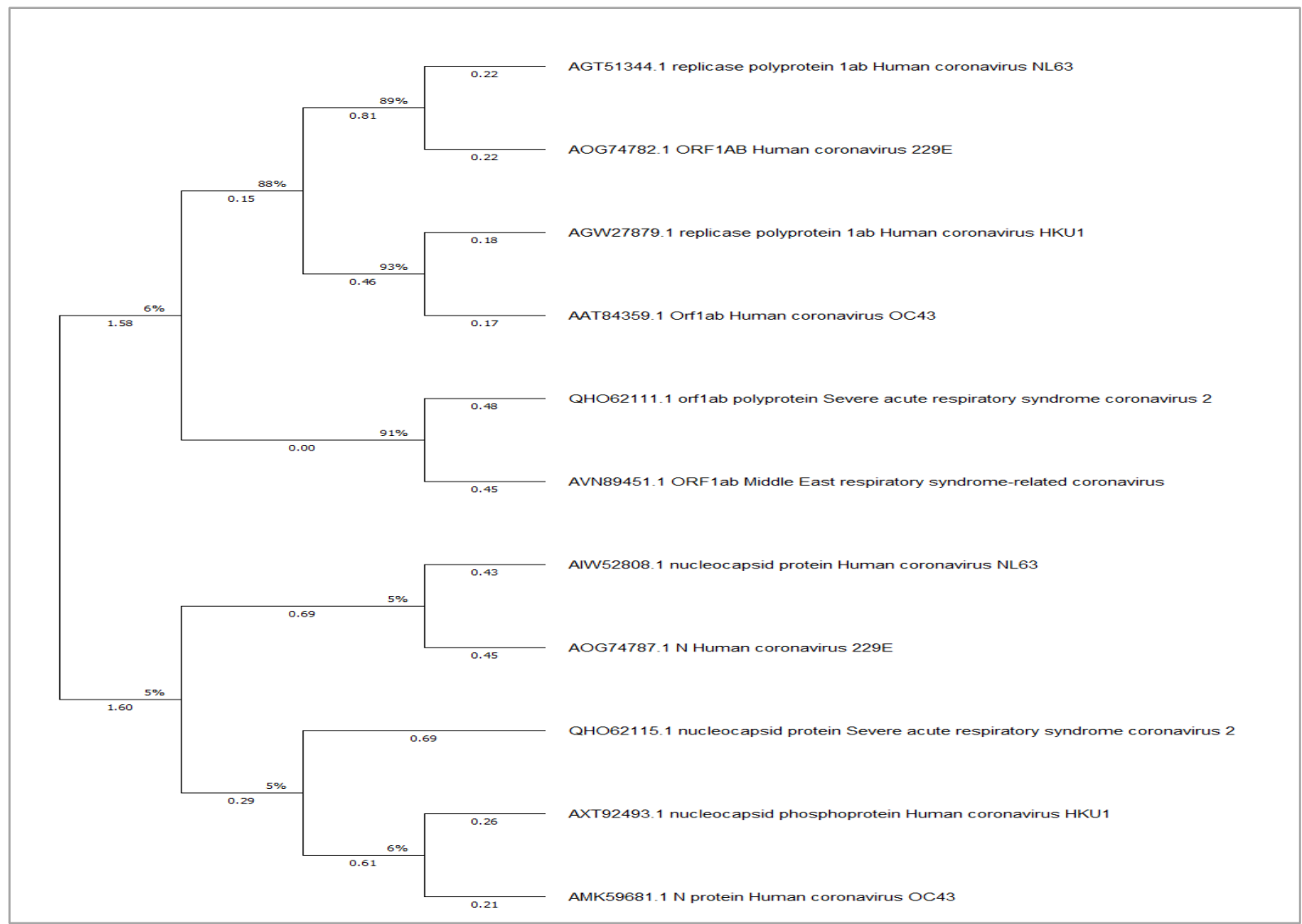

(D)

Figure 6: phylogenetical Analysis of $\mathrm{HCoV}$ Envelope (E), Spike (S), Membrane (M) and Nucleocapsid (N) protein. A: Similarity of Protein E, B: Similarity of Protein M, C: Similarity of Protein S, D: Similarity of Protein N.

\section{Host factors}

Figure 7 shows the host spectrum of the different coronavirus species. The species represented in blue are group 1 coronaviruses, those in red are group 2 coronaviruses and group 3 coronaviruses in black (avian coronavirus). The arrows indicate the hypothetical crossing of monetary barriers with emerging success. Although human viruses, HCoVs have at some point emerged from an animal reservoir, with the original viruses being chiropterans (HCoV-229E, HCoV-NL63) or rodents (HCoV-OC43, HCoV-
HKUl), with the putative intermediate hosts being cattle for $\mathrm{HCoV}$ OC43 and camelids for $\mathrm{HCoV}-22928^{[28]}$. In addition Malnutrition has been reported as a virulence factor for the SARS-CoV-2 infection. The malnutrition (hyponutrition and hypernutrition) is associated with immune dysfunction. The hyponutrition which is mainly protein deficiency is associated with low immuno-reactivity that lead to $\mathrm{T}$ cell function reduction, induction of IL4 and IL10 production, vitamins (A, B, D and E) deficiencies, hence the anaemia and micronutriment deficiencies. These conditions are surely associated with increased SARS-CoV-2 virulence.

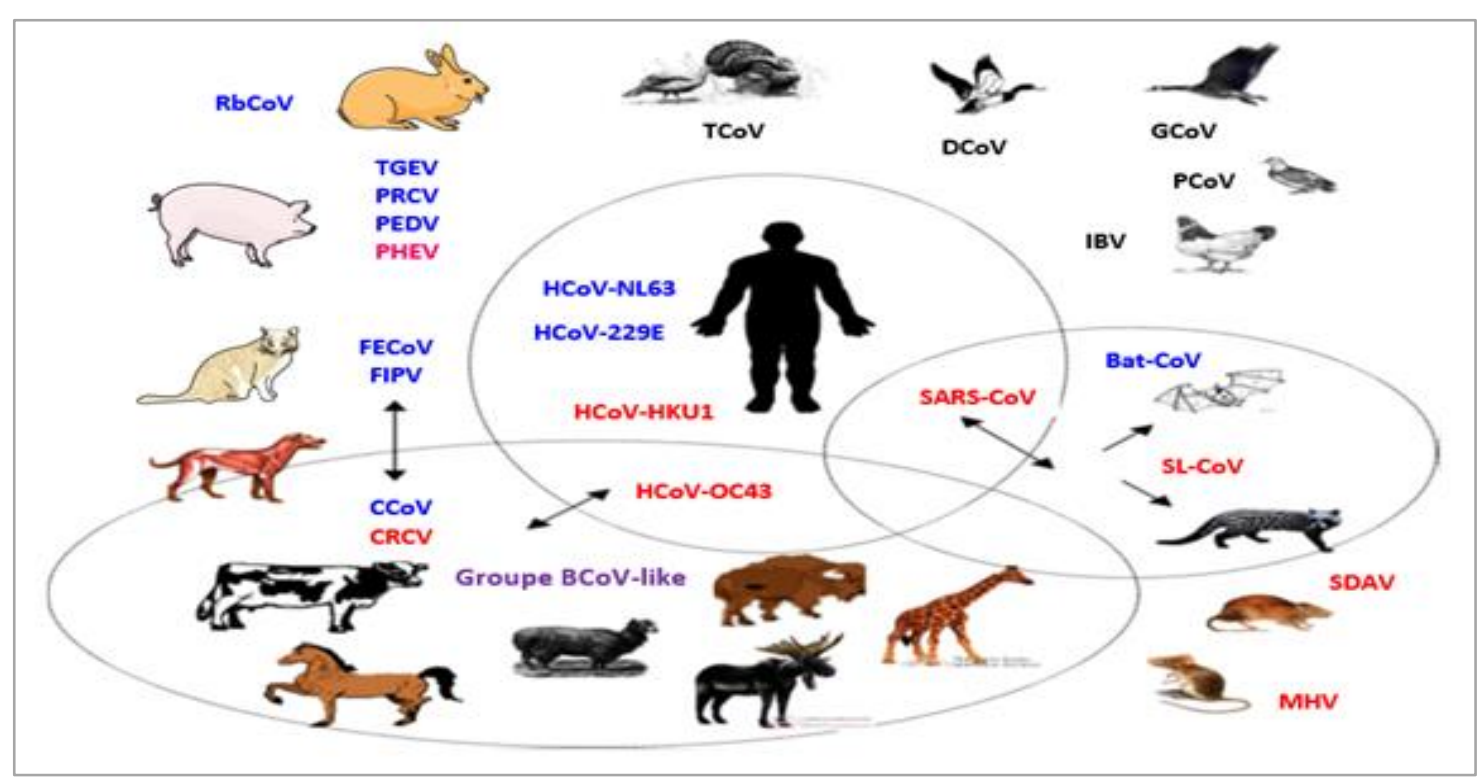

Figure 7: Host spectrum of different coronavirus species. Group 1 coronaviruses are written in blue, group 2 coronavruses in red, and group 3 coronaviruses (avian coronaviruses) in black. The arrows indicate the hypothetical crossing of cash barriers with emergent success. 
The hypernutrition which is essentialy do to sedentarism has the reverse effect. The immune dysregulation that exists in malnutrition and obesity can ahance the susceptibility to SARSCoV-2 infection (Figure 8) ${ }^{[35-37]}$. Malnourished people may have an immune deficiency to adequately fight against the virus. Malnourished individuals may be more susceptible to SARS-CoV-
2 infection. Nutritional support is there for vital in severe Covid-19 patients ${ }^{[36]}$. The most relevant co-factor of SARS-CoV-2 is immune disfuntion. Also older age, comorbid conditions and poli pharmacotherapy are the essential factors that increased the disease susceptibility.

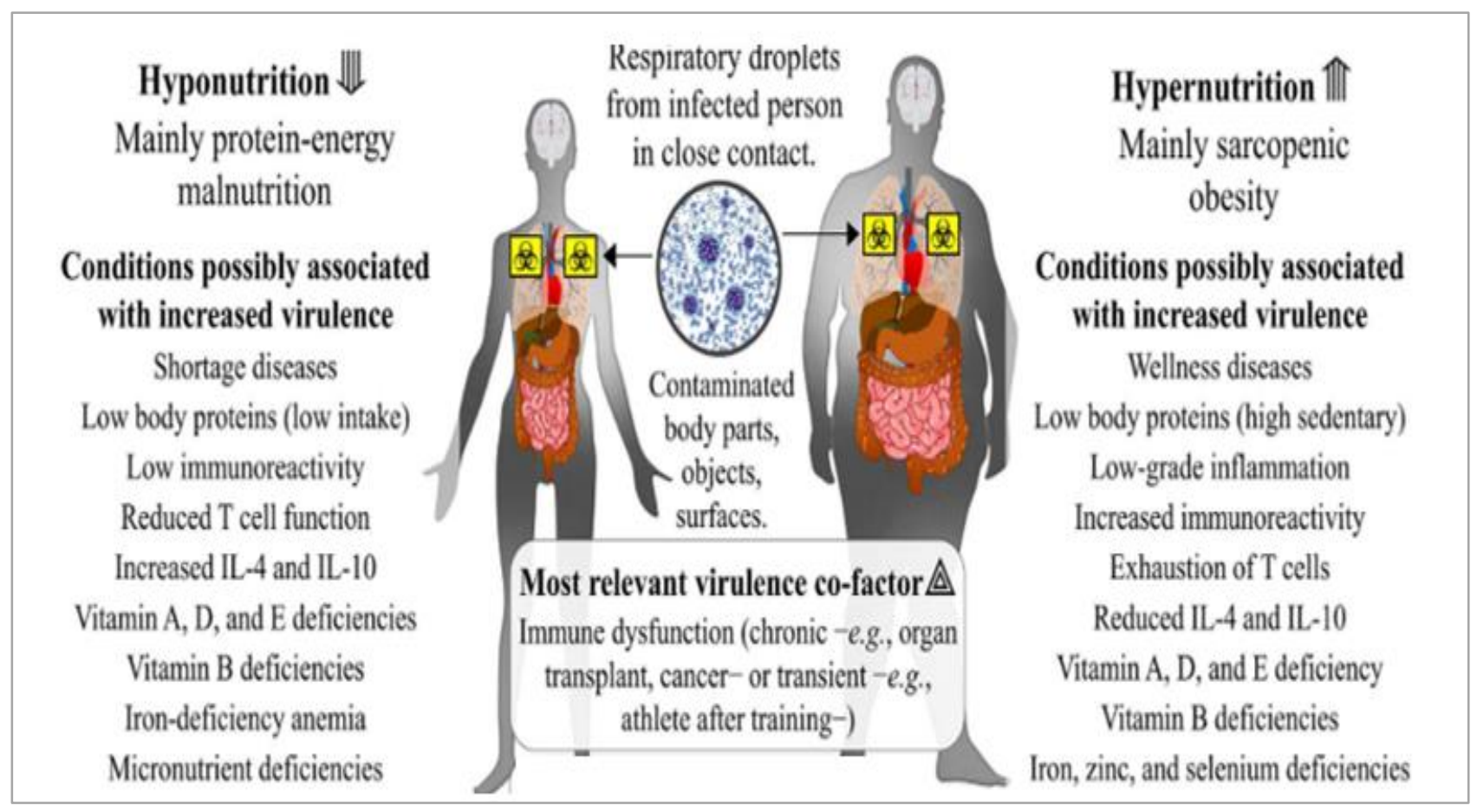

Figure 8: Malnutrition as virulence factor to coronavirus disease 2019 (Adapted from 115).

\section{Pathophysiology}

The pathophysiology of $\mathrm{HCoV}$ is linked to the function of both the nsp and the structural proteins. Some studies underlined that nsp areable to block the host innate immune response ${ }^{[38]}$. Coronaviruses starting the synthesis of polyprotein $1 \mathrm{a} / 1 \mathrm{ab}$ (ppla/pp1ab) in the host ${ }^{[16,39]}$, of both pp1a and pplab polypeptides that are processed by virally encoded chymotrypsinlike protease (3CLpro) or main protease (Mpro), as well as one or two papain-like proteases for producing 16 non-structural proteins (nsp) ${ }^{[40]}$. In addition, other ORFs encode structural proteins, such as spike, membrane, envelope, nucleocapsid proteins and accessory protein chains ${ }^{[41-43]}$.

Non-structural protein 1 (Nsp1) from severe acute respiratory syndrome coronavirus suppresses host cell protein synthesis by binding to the $40 \mathrm{~S}$ ribosomal subunit and endonucleolytically cleaving host mRNA ${ }^{[44]}$. This slows down translation in the infected cells and prevents, the proper expression of host factors that may be involved in the fight against the virus and its subsequent clearance by the innate immune. While Nsp1 prevents the expression of host proteins, viral protein synthesis continues unimpeded ${ }^{[45]}$.

The function of nsp2 is not fully understood. It is thought to be associate with the host endosome and host cell stability ${ }^{[46]}$. It is reported to be one of the conserved proteins of coronaviruses play a key role in viral replication in culture. Nsp2 and nsp3 of SARS-CoV are detected not only as mature processed proteins but also as precursors of nsp1 and nsp3, which conferred them a role as precursors in replication. These results suggest that nsp2 may be involved in the regulation of nsp1 and nsp3 functions ${ }^{[47]}$.

It has been reported that nsp3, nsp4, and nsp6 contain trans membrane domains and are likely to be involved in membrane anchoring of the replication complex ${ }^{[48,49]}$. Np3, also known as papain-like protease (PLPro), is the largest non-structural protein encoded by the coronavirus ( $\mathrm{CoV}$ ) genome, with an average molecular mass of about 200 Kdand the second most promising vaccine candidate besides $S$ protein ${ }^{[50]}$. It has different domain organization according to each Corona virus genera. The nsp3 releases nsp1 and nsp2 from polyproteins and interacts with not only the other viral nsps but also RNA to form a replication/transcription complex. nsp3 interacts with host protein translation to block host innate immunity, promote cytokine expression and is also responsible for the survival of the virus within the host by interfering with host proteins ${ }^{[51]}$. nsp3 interact with nsp4 to playa key role in the replication of SARS-CoV inside the infected cells ${ }^{[52]}$. Nsp6 alone has membrane proliferation properties. As for Nsp5, it is a cysteine protease wich is also called, the main protease (Mpro). Nsp5 plays a major role in the virus replication making MPro a potential and safe target for anti-CoV drug design. Nsp7 and nsp8 form an exadecameric complex. The both act as RNA polymerase primase and forms a replicase complex for replication and transcription of the viral RNA genome [53]. It was found that there is an inter connection between the major nsp of SARS-CoV. Thus, nsp12 bound to nsp7/nsp8complex and play a central role in the viral replication ${ }^{[54]}$. It is the most conserved protein in coronaviruses and an RNA-dependent RNA polymerase (RdRp) wich is the key enzyme in the viral replication/transcription complex. The nsp7/nsp8 complex increases binding of nsp12 to RNA ${ }^{[55]}$. Nsp9 is a single-stranded RNA-binding protein wich is also implicated in the virus virulence. It ha been reported that nsp9 also interact with Nsp7/Nsp8 complex and is essential for the viral replication and potential target of drug development against the SARS-CoV-247. Nsp10 is a small, singledomain protein having $99 \%$ sequence identity with SARS-CoV Nsp10. Nsp10 acts as a scaffold protein to form the mRNA cap 
methylation complex with Nsp14 (exonuclease and N7methyltransferase) and Nsp16 (2'-O-methyltransferase). It's there for a cofactor of nsp14 and nsp16 which enhance their activities ${ }^{[56]}$. Nsp 13 is the 1 helicase superfamily with plays an essential role in viral replication and conservation across all $\mathrm{CoV}$ species ${ }^{[57]}$. Nsp15 is a nidoviral RNA uridylate-specific endoribonuclease (NendoU) belonging to Endo U enzymes family. Firstly, nsp15 was thought to be able to bind RNA and involved in viral replication, then it was shown that it's rather responsible for the protein interference with the innate immune response. Other studies suggested that Nsp15 mediate the virus evasion of the host immune system. Recent data proved that this mechanism is not regulated by NendoU activity ${ }^{[58,59]}$. The Non-Structural Proteins (nsp) of Coronavirus and their biological functions are resumed in Table 1.

NAB nucleic acid binding, PL Pro papain-like protease, SUD SARS-unique domain, DMVs double-membrane vesicles, Mpro main protease, RdRp RNA-dependent RNA polymerase, MTase methyltransferase, Exo N viral exoribonuclease, Nendo U viral endoribonuclease, MDA5 melanoma differentiation associated protein 5, Ublubiquitin-like, Acacidic, 2'-O-MT 2'-Omethyltransferase, ADRP ADP-ribose-1'-phosphatase.

Table 1: Coronavirus non-structured proteins and their biological functions

\begin{tabular}{|l|l|}
\hline Protein & Functions \\
\hline$n s p 1$ & Promotes cellular mRNA degradation and blocks host cell translation, results in blocking innate immune response \\
\hline$n s p 2$ & No known function, binds to prohibiting proteins \\
\hline$n s p 3$ & Large, multi-domain transmembrane protein, activities include \\
\cline { 2 - 2 } & $\bullet$ Ubl1 and Ac domains, interact with N protein \\
\cline { 2 - 2 } & ADRP activity, promotes cytokine expression \\
\cline { 2 - 2 } & PLPro/Deubiquitinase domain, cleaves viral polyprotein and blocks host innate immune response \\
\cline { 2 - 2 } & Ub12, NAB, G2M, SUD, Y domains, unknown functions \\
\hline$n s p 4$ & Potential transmembrane scaffold protein, important for proper structure of DMVs \\
\hline$n s p 5$ & Mpro, cleaves viral polyprotein \\
\hline$n s p 6$ & Potential transmembrane scaffold protein \\
\hline$n s p 7$ & Forms hexadecameric complex with nsp8, may act as processivity clamp for RNA polymerase \\
\hline$n s p 8$ & Forms hexadecameric complex with nsp7, may act as processivity clamp for RNA polymerase; may act as primase \\
\hline$n s p 9$ & RNA binding protein \\
\hline$n s p 10$ & Cofactor for nsp16 and nsp14, forms heterodimer with both and stimulates ExoN and 2-O-MT activity \\
\hline$n s p 12$ & RdRp \\
\hline$n s p 13$ & RNA helicase, 5' triphosphatase \\
\hline$n s p 14$ & $\begin{array}{l}\text { N7 MTase and 3'-5' exoribonuclease, ExoN; N7 MTase adds 5' cap to viral RNAs, ExoN activity is important for proofreading } \\
\text { of viral genome }\end{array}$ \\
\hline$n s p 15$ & Viral endoribonuclease, NendoU \\
\hline$n s p 16$ & 2'-O-MT; shields viral RNA from MDA5 recognition \\
\hline
\end{tabular}

\section{Epidemiology of coronavirus disease}

In 2003, an epidemic of severe respiratory disease, severe acute respiratory syndrome (SARS), occurred in Guandong Province, China which quickly spread to other provinces in China. Intensive international research identified the new virus and see that it has the same morphological characteristics as and genetic characteristics of coronaviruses ${ }^{[60]}$ and was called SARS-CoV. Recommendations for travel and measures to control the spread of the epidemic (rapid detection of cases, isolation, wearing of masks, etc.) were quickly issued by the WHO and quickly stopped the transmission of the virus ${ }^{[61,62]}$. At the beginning of July 2003, no further transmission of the virus was observed and transmission was no longer observed and the WHO considered that the epidemia was contained. Some isolated cases, were identified between September 2003 and January 2004, with no other transmissions. It was then established that the natural host of the virus that causes SARS-CoV was a bat ${ }^{[63]}$. In 2012, Middle East Respiratory Syndrome Coronavirus (MERS-CoV) was identified in a patient with died of pneumonia in Saudi Arabia and a wave of severe pneumonia had occurred like previously in Jordan due to the same MERS-CoV ${ }^{[64]}$. Coronaviruses genetically very similar to MERS$\mathrm{CoV}$ have been identified in bats that represent the virus reservoir. Humans become infected through contact with dromedaries, which are intermediate hosts. Human-to-human transmission was not really established, the few cases observed were nosocomial infections ${ }^{[65]}$.

The occurrence of severe pneumonia has been observed in December 2019 in the city of Wuhan, China. A new coronavirus associated with this outbreak was identified in early January 2020 ${ }^{\text {[66] }}$ and the disease, which emerged in 2019, was named Covid (Coronavirus disease)-19. The epidemic has spread rapidly outside China and all over the world. It is reported that the rapid emergence of SARS-CoV-2 and its pandemic spread are a proof that this virus is far more contagious than SARS-CoV-1 and MERS-CoV ${ }^{[26]}$.

From MERS-CoV to SARS-CoV-2, the transmission has been identified as airborne droplet transmission ${ }^{[67]}$. The human coronavirus infection's incubation periods are short. It is around three days for conventional $\mathrm{CoV}$ (HCoV-229E and HCoV-OC43), two to ten days for SARS-CoV (SARS-CoV and MERS -CoV) and two to fourteenth days for SARS-CoV-2 ${ }^{[68]}$ (Table 2).

The duration of the viral excretion in the respiratory tract is less well known, the RNA of conventional $\mathrm{HCoV}$ is detectable for about 14 days in the respiratory tract ${ }^{[69,70]}$. SARS-CoV RNA can be detected by reverse transcriptase - polymerase chain reaction (RT-PCR) in the patient's respiratory secretions, stool, and urine up to approximately 30 days after the onset of the clinical signs ${ }^{[71]}$. 
Table 2: Epidemiology of Human coronaviruses. ARE: acute respiratory illness, CoV: coronavirus, ILI "influenza-like illness", MERS "Middle East respiratory syndrome", SARS "severe acute respiratory syndrome

\begin{tabular}{|c|c|c|c|c|c|c|c|}
\hline & $\begin{array}{l}\text { SARS-CoV } \\
2\end{array}$ & MERS-CoV & SRAS-Cov1 & $\begin{array}{l}\mathrm{HCoV}- \\
\mathrm{HKU} 1\end{array}$ & $\begin{array}{l}\text { HCoV- } \\
\text { NL63 }\end{array}$ & $\begin{array}{l}\mathrm{HCoV}- \\
229 \mathrm{E}\end{array}$ & $\begin{array}{l}\mathrm{HCoV}- \\
\mathrm{OC} 43\end{array}$ \\
\hline Discovery & 2019 & 2012 & 2004 & 2004 & 2003 & 1960 & $\begin{array}{l}1960 \\
\end{array}$ \\
\hline $\begin{array}{l}\text { Source of infection for } \\
\text { humans }\end{array}$ & - & $\begin{array}{l}\text { Dromedarie, } \\
\text { human }\end{array}$ & $\begin{array}{l}\text { leather mouse, } \\
\text { crawling cats, human }\end{array}$ & human & human & human & human \\
\hline Transmission & $\begin{array}{l}\text { Airborne } \\
\text { droplet }\end{array}$ & $\begin{array}{l}\text { Airborne } \\
\text { droplet }\end{array}$ & Airborne droplet & $\begin{array}{l}\text { Airborne } \\
\text { droplet }\end{array}$ & $\begin{array}{l}\text { Airborne } \\
\text { droplet }\end{array}$ & $\begin{array}{l}\text { Airborne } \\
\text { droplet }\end{array}$ & $\begin{array}{l}\text { Airborne } \\
\text { droplet }\end{array}$ \\
\hline Infection period & - & Spring & Spring & $\begin{array}{l}\text { Winter - } \\
\text { Spring }\end{array}$ & $\begin{array}{l}\text { Winter - } \\
\text { Spring }\end{array}$ & $\begin{array}{l}\text { Winter - } \\
\text { Spring }\end{array}$ & $\begin{array}{l}\text { Winter - } \\
\text { Spring }\end{array}$ \\
\hline $\begin{array}{l}\text { Focus of geographic } \\
\text { distribution }\end{array}$ & Worldwide & $\begin{array}{l}\text { Arabian } \\
\text { Peninsula }\end{array}$ & $\begin{array}{l}\text { No more human cases } \\
\text { since } 2004 \text { (previously } \\
\text { East Asia) }\end{array}$ & Worldwide & Worldwide & Worldwide & Worldwide \\
\hline Typical clinic & $\begin{array}{l}\text { Viral } \\
\text { pneumonia }\end{array}$ & $\begin{array}{l}\text { Viral } \\
\text { pneumonia }\end{array}$ & Viral pneumonia & ARE, ILI & ARE, ILI & ARE, ILI & ARE, ILI \\
\hline Case fatality rate (CFR) & $\sim 7.1 \%{ }^{\mathrm{a}}$ & & $9.6-11 \%$ & - & - & - & - \\
\hline Incubation time & $2-14$ days & $2-7$ days & $2-7$ days & 2-3 days & 2-3 days & 2-3 days & 2-3 days \\
\hline
\end{tabular}

\section{Genome similarity and conserved regions}

The size of the genome and the complexity of the replication mode of coronaviruses granted them a high evolutionary potential.

The two major modes of evolution of coronaviruses are mutations and recombination ${ }^{[37,72]}$. The mutation is due to an RNA dependent RNA-polymerase (RdRp), devoid of error correction system and generating many mutants replicates of RNA genomic. As with all RNA viruses, the viral population is heterogeneous and has a distribution in quasi-species. This distribution can be seen as an optimization strategy, being a structure allowing having a reservoir of variants with the capacities to cope with environmental changes.

It has been described for several coronaviruses not only in the context of persistent infections, but also in acute infections [73-76]. The best-known example is the emergence of respiratory porcine coronavirus (PRCV) in the 1980s, which is a spontaneous variant (deletion of 672 nucleotides ( 224 amino acids) in the gene encoding the protein S1) of enteric porcine coronavirus (TGEV). One of the biological consequences of this great deletion is the change in the tropism of the virus, from the TGEV to respiratory for PRCV [77].

The other evolutionary mode of coronaviruses is genetic recombination. This phenomenon is frequent in positive RNA viruses and seems to be favored in coronaviruses by the discontinuous mode of transcription. Recombination is the exchange of genetic material, which can be homologous if it takes place between two coronaviruses genomes, or heterologous if it involves other viral or cellular genes. Many recombinant forms have been described in vitro and in vivo in coronaviruses.

For example, feline coronavirus type II is the result of a double recombination between feline coronavirus type I and canine coronavirus, following a crossing of a species barrier in the dog-cat direction ${ }^{[78]}$. The important evolutionary capacity of coronaviruses was highlighted by the emergence of SARS-CoV ${ }^{[79]}$. The complete sequencing of HCoV-OC43 genome in 2005 by Vijgenet al. has further shown that this coronavirus is very close to bovine coronavirus, with more than $90 \%$ of nucleotide identity and on the other hand the $\mathrm{E}$ gene would have been acquired following a recombination with the porcine coronavirus of group 2 and hemagglutination encephalitis virus (HEV) ${ }^{[12,80]}$. These data strongly suggest an emergence of HCoV-OC43 in the human population, secondary to an interspecies transmission in the bovine
- human sense, which would have occurred at the end of the XIX ${ }^{\text {th }}$ century ${ }^{[81,82]}$.

Several coronaviruses belonging to group $2 \mathrm{a}$ and with the same molecular lineage as $\mathrm{HCoV}-\mathrm{OC} 43$ and $\mathrm{BCoV}$ have been recently described in elk, buffalo, giraffe, horse, and dog ${ }^{[83,84]}$. It therefore seems that this group 2a "BCoV-like" coronavirus has a very broad host spectrum in wild and farmed mammals and has a high potential for interspecific passage ${ }^{[85]}$. Otherwise, the comparison of SL-CoV genomes from civets with the human SARS-CoV sequences shows approximately 30000 nucleotides (a total of 212 positions of variation) of which 209 in a protein coding region (73 of these 209 are silent) ${ }^{[85,86]}$.

The SARS-CoV sequences of the early period (November 2002 to January 2003) are close to the SL-CoV sequences of civets, in particular the existence of a sequence of 29 nucleotides located at the level of ORF8, which has then disappeared when the virus adapted to humans (deletion of 29 nucleotides) ${ }^{[65,87]}$. During the evolution of SARS-CoV, the mutation of amino acid residue 487 (from serine in civets to threonine in humans) of protein $\mathrm{S}$ seems to have contributed significantly to the adaptation of SARS-CoV to the human receptor angiotensin-converting enzyme 2 (ACE2) ${ }^{[88-90]}$. The percentage of similarity of sequences in six bat SL-CoV genomes has shown 89 to $90 \%$, and around 87 to $92 \%$ with the civet sequences SL-CoV and SARS-CoV. The most variable regions are the S gene (76$78 \%$ similarity) and ORF8.

The $29 \mathrm{nt}$ region found in SL-CoV civets and early stage human strains is also found in SL-CoV bat ${ }^{[91]}$. Sequence analysis of SARS-CoV-2 has shown a typical structure to other coronavirus and its genome has been linked to a previously identified coronavirus strain, SARS-CoV that caused the SARS outbreak in $2003{ }^{[92]}$. Structurally, the SARS coronavirus (SARS-CoV) has a well-defined composition comprising 14 binding residues that directly interact with human ACE2. Of these amino acids, eight have been conserved in SARS-CoV-2 ${ }^{[93]}$.

Although the exact pathophysiological mechanisms underlying the emergence of SARS-CoV-2 are unknown, genomic similarities to SARS-CoV could help to explain the resulting inflammatory response that may lead to the onset of severe pneumonia ${ }^{[94]}$.

The HCoV structure has shown that there are most surface proteins, which have hypervariable regions, allowing it to escape immune pressure and, if necessary, to be able to enlarge its cellular tropism. Protein S of coronaviruses has a weak 
hemagglutination activity and binds to sialic acids. However, entry into target cells appears to require interaction with a specific protein receptor. Thus, cellular receptors are identified for some coronaviruses: CEACAM1 molecule for the MHV, amino peptidase N (APN) or CD13 for several group 1 coronaviruses (HCoV-229E, TGEV and PRCV, canine coronavirus and felines), the ACE2 molecule for HCoV-NL63 and SARS-CoV ${ }^{[63,95]}$. The interactions between the protein $\mathrm{S}$ and its receptor seems complex and a large amount of data remains misunderstood.

The site of binding of the protein $\mathrm{S}$ to its receptor (receptor binding domain [RBD]) is located in different regions of the protein depending on the species of coronavirus, and its cleavage into its two subunits S1 and S2 is variable, depending on the coronavirus and the cell type ${ }^{[96]}$. Some experimental data are unexpected: despite the amino acid sequences conserved at the level of the S1 protein of HCoV-229E and HCoV-NL63, these two human coronaviruses use different receptors (APN and ACE2, respectively). Furthermore, SARS-CoV uses the same cellular receptor as HCoV-NL63 while the S1 sequences are far apart; however, the RBD of the two viruses seems to be close and absent in SL-CoV.

The hypothesis is posed of an acquisition of this domain by recombination between SARS-CoV and another coronavirus close to HCoV-NL63 during its evolution in humans ${ }^{[97,98]}$. The apparent plasticity of protein $\mathrm{S}$ and $\mathrm{RBD}$ would allow coronaviruses to adapt to different protein receptors or to heterologous receptors in different species and would be an advantage in emerging in new hosts. Group 2a coronaviruses are characterized by the existence of an HE protein, which forms a double row of small spicules of five nm high on the surface of the virus. It is a dimeric protein with hemagglutination activity and acetyl esterase. The gene encoding this protein is characteristic of group 2a CoVs. However, its expression is very variable.

Thus, in most MHV isolates, mutations, deletions or insertions have led to the loss of the open reading frameof this gene. Among the human coronaviruses, only the HCoV-OC43 and HCoV-HKU1 strains have the gene encoding HE ${ }^{[99,100]}$. There is approximately $28 \%$ homology between the HEF surface protein of influenza $\mathrm{C}$ virus and the $\mathrm{HE}$ protein of $\mathrm{HCoV}-\mathrm{OC} 43$ and bovine coronaviruses $(\mathrm{BCoV})$.

Since the influenza $\mathrm{C}$ and $\mathrm{HCoV}-\mathrm{OC} 43$ viruses infect the same tissues in humans, this homology suggests the acquisition of this gene by recombination. It should be noted that the HEF protein of the Influenza $\mathrm{C}$ virus has a membrane fusion activity, which is absent in the HE protein of $\mathrm{CoV}{ }^{[101,102]}$. This protein recognizes cell receptors containing acetylated 9-O sialic acids and induces the formation of neutralizing antibodies. Thus, it would have a function of attachment protein and of initiation of the infection, additive to that of protein $\mathrm{S}$. However, its main function would be the acetyl-esterase activity. Many questions exist about the in vivo course of the first stages of the replication cycle for Group 2a CoVs. The HE protein required little attention, probably because it would not be present in the CoVs most studied so far (IBV, MHV, TGEV, SARS- CoV, HCoV-229E and HCoV-NL63) ${ }^{[103,104]}$. For all Group 2a CoVs studied so far, the binding of protein $S$ to a sialic acid corresponds with the preferential substrate of HE. The HE protein would therefore allow optimal use of sialic acids as attachment factors.

The mode of entry of $\mathrm{CoV}$ expressing the HE protein would then be close to that adopted by the influenza A and B viruses, and the functional balance described between hemagglutinin and neuraminidase HA/NA could also exist between $\mathrm{S}$ and $\mathrm{HE}{ }^{[85]}$. Protein $\mathrm{S}$ is the factor that determines the host spectrum and tissue tropism of coronavirus strains and is the carrier where the differences between $\mathrm{HCoV}, \mathrm{BCoV}$ and civet coronavirus are concentrated ${ }^{[82]}$. Cellular protein receptors, in addition to binding to sialic acids have been described for a number of coronaviruses. However, some coronavirus, such as $\mathrm{BCoV}$ and HCoV-OC43, use only a sialic acid as the same used by the influenza $\mathrm{C}$ virus.

Epidemiology transmission of $\mathrm{HCoV}$ occurs mainly directly through droplets of oropharyngeal secretions dispersed by the cough of an infected or symptomatic person. During SARS, MERS and Covid-19, those infected are mainly person who had close contact with a positive case. Airborne viral spread appears to be infrequent as well as indirect "hand-carried" transmission. However, these transmission routes must be taken into account for the control of epidemics, especially in healthcare settings.

Studies of "survival" or maintenance of pathogenicity in air is rare and difficult. The number of secondary cases from index case was only studied within the framework of SARS in 2003. This virus is moderately contagious, with an average number of secondary cases estimated at 2.2 to 3.6. However, superpropagation events with several dozen secondary cases have been described, and have played an important role in the spread of the disease $^{[105]}$.

Concerning old outbreak of the human coronaviruses, among the classic coronavirus strains isolated in the 1960s, only $\mathrm{HCoV}-229 \mathrm{E}$ and HCoV-OC43 were studied and maintained in culture ${ }^{[106]}$. These studies have shown that $\mathrm{HCoV}$ represents a group of respiratory pathogens that infects all age groups and involves in lower respiratory infections (bronchitis, bronchiolitis, pneumonitis, exacerbations of asthma) ${ }^{[107]}$. The primary infections occur in the early years and re-infections are common throughout life. These reinfections are symptomatic in approximately $45 \%$ of cases. The infection rate is relatively uniform across all age groups.

This situation differs from other observed for respiratory viruses such as respiratory syncytial virus (RSV), for which infection rates decrease with age. The classic coronaviruses circulate in an epidemic mode, most often between January and May in areas with a temperate climate. The cyclical and alternative nature of $\mathrm{HCoV}-229 \mathrm{E}$ and $\mathrm{HCoV}-\mathrm{OC} 43$ strains had been stressed as well as the probable existence of other serotypes. That suggested the combined use of several serological techniques such as complement fixation, inhibition of hemagglutination and seroneutralization ${ }^{[80]}$.

Regarding HCoV-NL63 and HCoV-HKU1, their recent identification reflects a reduced number of epidemiological data. HCoV-NL63 is a group 1 coronavirus that was discovered and identified by molecular techniques from a respiratory sample of a seven-month-old infant hospitalized for bronchiolitis in January 2003 and the prototype strain was called Amsterdam $1^{[95]}$. The retrospective studies have shown that $\mathrm{HCoV}-\mathrm{NL63}$ is not an emerging virus but a virus already circulating in the human population and newly identified ${ }^{[108]}$.

HCoV-HKU1 is a group 2a coronavirus, discovered in Hong Kong in 2005, in a 71-year-old patient hospitalized for pneumonia. This virus has been characterized on a molecular level and determined three different genotypes; A, B, and $\mathrm{C}$ of $\mathrm{HCoV}$ HKU1, genotype $\mathrm{C}$ being a recombinant of genotypes $\mathrm{A}$ and $\mathrm{B}$. In addition, this virus is not responsible for a new disease, only its knowledge is emerging ${ }^{[109]}$. HCoV-HKU1 has not been adapted to cell culture.

In 2006 and 2007, some studies were published on the circulation of the four HCoVs (HCoV-229E, HCoV-OC43, HCoVNL63 and HCoV-HKU1). These studies have nonetheless 
confirmed the epidemic nature of human coronavirus infections, at the winter - spring junction (peak in February). The four HCoV cocirculate with variations in the distribution of different species according to geography and years ${ }^{[110]}$. SARS is a special story in coronavirus infections.

According to the WHO, on March $12^{\text {th }}, 2003$, SARS$\mathrm{CoV}$ made about 8000 probable cases and 800 deaths were declared, the great majority in China. The estimated fatality rate is $0 \%$ for subjects under 35 years of age, $7 \%$ for subjects 35 to 65 years of age, and $47 \%$ for subjects over 65 years of age. WHO declared the end of human-to-human transmission in July $2003^{[8]}$. Since July 2003, several cases of laboratory contamination have been reported in Asia; finally, epidemiological reports from the Guangdong Center for Disease Control and Prevention have indicated that in January 2004, six months after the end of the epidemic, four patients were hospitalized for a mild SARS-CoV infection. The molecular study of these strains concluded that they derived from the same source as the epidemic strains from 2002 to $2003^{[8,95]}$.

MERS-CoV triggered an occurrence of respiratory illness in the Middle East with secondary spread to Europe, Africa, Asia, and North America. The diseases occurred mainly in the Middle East states with highest cases of $88 \%$ followed by $11 \%$ in Asia, $0.8 \%$ in Europe, $0.1 \%$ in Africa and $0.1 \%$ in USA. The age group with highest risk for acquiring as primary cases of infections is 50-59 years and high risk for acquiring as secondary cases of infections is 30-39 years. The total number of associated fatality rate is $858(34.40 \%)^{[111]}$

Recent coronavirus outbreak was due to a novel SARSCoV-2 coronavirus. In December 2019, reports of pneumonia-like conditions came in Wuhan, China. The viral spillover is believed to happen in a seafood market in Wuhan, Hubei Province, China ${ }^{[112]}$. WHO declared Covid-19 to be a public health emergency of international concern (PHEIC) on 30th January $2020^{[113]}$.

\section{Conclusion}

A new member of SARS-CoV species has emerged. SARS-CoV comprised now SARS-CoV, MERS-CoV and SARS-CoV-2 and the four seasonal circulating human coronaviruses ( $\mathrm{HCoV} 229 \mathrm{E}$, HCov-HKU1, HCov-NL63 and OC43) which represent the most circulating Human coronavirus detected. In addition, SARS-CoV-2 is the most pathogen $\mathrm{HCoV}$ and its outbreak locked down the world as never seen before. Scientists must focus on the mutation capacities of the coronavirus in order to predict the emergence of SARS-CoV epidemics.

\section{Conflict of Interest}

Submitting authors are responsible for co authors declaring theirs interest.

\section{References}

[1] Katawa G, Layland LE, Debrah AY, et al. Hyperreactive onchocerciasis is characterized by a combination of Th17-Th2 immune responses and reduced regulatory $\mathrm{T}$ cells. PLoS Negl Trop Dis. Jan 2015;9(1):e3414. doi:10.1371/journal.pntd.0003414

[2] Katawa G, Kolou M, Nadjir LK, Ataba E, Bomboma G, Karou SD. CD4 T-Lymphocytes Count in HIVToxoplasma gondii Co-Infected Pregnant Women Undergoing a Prevention of Mother-to-Child
Transmission Program. Journal of Biosciences and Medicines. 2018;6(04):76.doi: 10.4236/jbm.2018.64006

[3] Nadjir LK, Kolou M, Katawa G, et al. Seroprevalence of hepatitis $\mathrm{B}$ virus, hepatitis $\mathrm{C}$ virus, and human immunodeficiency virus among volunteer blood donors in the National Blood Transfusion Center of Lom. Int $\mathbf{J}$ Blood Transfus Immunohematol. 2017;7:41-45. doi:10.5348/ijbti-2017-33-OA-6

[4] Kolou M, Katawa G, Salou M, et al. High Prevalence of Hepatitis B Virus Infection in the Age Range of 20-39 Years Old Individuals in Lome. Open Virol J. 2017;11:17. doi:10.2174/1874357901710011001

[5] Tchopba CN, Ataba E, Katawa G, et al. COVID-19: epidemiology, pathogenesis and immununological basis. Al-Nahrain Journal of Science. 2020;(4):1-12. doi:10.22401/ANJS.00.4.01

[6] Chen Y, Liu Q, Guo D. Emerging coronaviruses: Genome structure, replication, and pathogenesis. J Med Virol. Oct 2020;92(10):2249. doi:10.1002/jmv.26234

[7] Kaushik S, Sharma Y, Kumar R, Yadav JP. The Indian perspective of COVID-19 outbreak. Virusdisease. May 2020:1-8. doi:10.1007/s13337-020-00587-x

[8] Adachi S, Koma T, Doi N, Nomaguchi M, Adachi A. Commentary: Origin and evolution of pathogenic coronaviruses. Front Immunol. 2020;11:811. doi:10.3389/fimmu.2020.00811

[9] Woo PC, Lau SK, Huang Y, Yuen KY. Coronavirus diversity, phylogeny and interspecies jumping. Exp Biol Med (Maywood). Oct 2009;234(10):1117-27. doi:10.3181/0903-MR-94

[10] Belouzard S, Millet JK, Licitra BN, Whittaker GR. Mechanisms of coronavirus cell entry mediated by the viral spike protein. Viruses. 06 2012;4(6):1011-33. doi:10.3390/v4061011

[11] Niu J, Shen L, Huang B, et al. Non-invasive bioluminescence imaging of $\mathrm{HCoV}-\mathrm{OC} 43$ infection and therapy in the central nervous system of live mice. Antiviral Res. $01 \quad$ 2020;173:104646. doi:10.1016/j.antiviral.2019.104646

[12] Lau SK, Lee P, Tsang AK, et al. Molecular epidemiology of human coronavirus OC43 reveals evolution of different genotypes over time and recent emergence of a novel genotype due to natural recombination. J Virol. Nov 2011;85(21):11325-37. doi:10.1128/JVI.05512-11

[13] Huynh J, Li S, Yount B, et al. Evidence supporting a zoonotic origin of human coronavirus strain NL63. J Virol. Dec 2012;86(23):12816-25. doi:10.1128/JVI.00906-12

[14] Oong XY, Ng KT, Takebe Y, et al. Identification and evolutionary dynamics of two novel human coronavirus OC43 genotypes associated with acute respiratory infections: phylogenetic, spatiotemporal and transmission network analyses. Emerg Microbes Infect. Jan 2017;6(1):e3. doi:10.1038/emi.2016.132

[15] Haake C, Cook S, Pusterla N, Murphy B. Coronavirus Infections in Companion Animals: Virology, Epidemiology, Clinical and Pathologic Features. Viruses. 09 2020;12(9).doi:10.3390/v12091023

[16] Vabret AD, J. Brison, E. Brouard, J. Freymuth, F. . Coronavirus humains (HCoV). Pathologie Biologie. 2009;(57):149-160. doi:10.1016/j.patbio.2008.02.018 
[17] Jin Y, Song JR, Xie ZP, et al. Prevalence and clinical characteristics of human CoV-HKU1 in children with acute respiratory tract infections in China. J Clin Virol. Oct 2010;49(2):126-30. doi:10.1016/j.jcv.2010.07.002

[18] Mallah SI, Ghorab OK, Al-Salmi S, et al. COVID-19: breaking down a global health crisis. Ann Clin Microbiol Antimicrob. May 2021;20(1):35. doi:10.1186/s12941021-00438-7

[19] Chu DKW, Pan Y, Cheng SMS, et al. Molecular Diagnosis of a Novel Coronavirus (2019-nCoV) Causing an Outbreak of Pneumonia. Clin Chem. 04 2020;66(4):549-555. doi:10.1093/clinchem/hvaa029

[20] Lu R, Zhao X, Li J, et al. Genomic characterisation and epidemiology of 2019 novel coronavirus: implications for virus origins and receptor binding. Lancet. 02 2020;395(10224):565-574. doi:10.1016/S01406736(20)30251-8

[21] Singh DD, Han I, Choi EH, Yadav DK. Recent Advances in Pathophysiology, Drug Development and Future Perspectives of SARS-CoV-2. Front Cell Dev Biol. 2020;8:580202. doi:10.3389/fcell.2020.580202

[22] Song X, Shi Y, Ding W, et al. Cryo-EM analysis of the HCoV-229E spike glycoprotein reveals dynamic prefusion conformational changes. Nat Commun. 01 2021;12(1):141. doi:10.1038/s41467-020-20401-y

[23] Nascimento Júnior JAC, Santos AM, Cavalcante RCM, et al. Mapping the technological landscape of SARS, MERS, and SARS-CoV-2 vaccines. Drug Dev Ind Pharm. Apr 2021; 47(4): 673-684. doi:10.1080/03639045.2021.1908343

[24] Graham RL, Donaldson EF, Baric RS. A decade after SARS: strategies for controlling emerging coronaviruses. Nat Rev Microbiol. Dec 2013;11(12):836-48. doi:10.1038/nrmicro3143

[25] Drexler JF, Corman VM, Drosten C. Ecology, evolution and classification of bat coronaviruses in the aftermath of SARS. Antiviral Res. Jan 2014;101:45-56. doi:10.1016/j.antiviral.2013.10.013

[26] Chung Y-S, Kim JM, Man Kim H, et al. Genetic Characterization of Middle East Respiratory Syndrome Coronavirus, South Korea, 2018. Emerging infectious diseases. 2019;25(5):958-962. doi:10.3201/eid2505.181534

[27] Zhou P, Yang X-L, Wang X-G, et al. Discovery of a novel coronavirus associated with the recent pneumonia outbreak in humans and its potential bat origin. BioRxiv. 2020.doi: 10.1038/s41586-020-2012-7

[28] Corman VM, Muth D, Niemeyer D, Drosten C. Hosts and sources of endemic human coronaviruses. Advances in virus research. 2018;100:163-188.doi: 10.1016/bs.aivir.2018.01.001

[29] Dai L, Gao GF. Viral targets for vaccines against COVID-19. Nat Rev Immunol. 02 2021;21(2):73-82. doi: 10.1038/s41577-020-00480-0.

[30] Naydenova K, Muir KW, Wu LF, et al. Structure of the SARS-CoV-2 RNA-dependent RNA polymerase in the presence of favipiravir-RTP. Proc Natl Acad Sci U S A. 02 2021;118(7)doi:10.1073/pnas.2021946118. doi: $10.1073 /$ pnas.2021946118

[31] Oliveira SC, de Magalhães MTQ, Homan EJ. Immunoinformatic Analysis of SARS-CoV-2 Nucleocapsid Protein and Identification of COVID-19
Vaccine Targets. Front Immunol. 2020;11:587615. doi:10.3389/fimmu.2020.587615

[32] Serrão VHB, Lee JE. FRETing over SARS-CoV-2: Conformational Dynamics of the Spike Glycoprotein. Cell Host Microbe. 12 2020;28(6):778-779. doi:10.1016/j.chom.2020.11.008

[33] Srinivasan S, Cui H, Gao Z, et al. Structural Genomics of SARS-CoV-2 Indicates Evolutionary Conserved Functional Regions of Viral Proteins. Viruses. 03 2020;12(4). doi:10.3390/v12040360

[34] Wrapp D, Wang N, Corbett KS, et al. Cryo-EM structure of the 2019-nCoV spike in the prefusion conformation. Science. $03 \quad 2020 ; 367(6483): 1260-1263$. doi:10.1126/science.abb2507

[35] Bhattacharya I, Ghayor C, Pérez Dominguez A, Weber FE. From Influenza Virus to Novel Corona Virus (SARS-CoV-2)-The Contribution of Obesity. Front Endocrinol (Lausanne). 2020;11:556962. doi:10.3389/fendo.2020.556962

[36] Almond MH, Edwards MR, Barclay WS, Johnston SL. Obesity and susceptibility to severe outcomes following respiratory viral infection. Thorax. Jul 2013;68(7):684-6. doi:10.1136/thoraxjnl-2012-203009

[37] Wang Y, Grunewald M, Perlman S. Coronaviruses: An Updated Overview of Their Replication and Pathogenesis. Methods Mol Biol. 2020;2203:1-29. doi:10.1007/978-1-0716-0900-2_1

[38] Fehr AR, Channappanavar R, Jankevicius G, et al. The Conserved Coronavirus Macrodomain Promotes Virulence and Suppresses the Innate Immune Response during Severe Acute Respiratory Syndrome Coronavirus Infection. mBio. 12 2016;7(6). doi:10.1128/mBio.0172116

[39] Romano M, Ruggiero A, Squeglia F, Maga G, Berisio R. A Structural View of SARS-CoV-2 RNA Replication Machinery: RNA Synthesis, Proofreading and Final Capping. Cells. 05 2020;9(5). doi:10.3390/cells9051267

[40] Niemeyer D, Mösbauer K, Klein EM, et al. The papainlike protease determines a virulence trait that varies among members of the SARS-coronavirus species. PLoS Pathog. $09 \quad 2018 ; 14(9):$ e1007296. doi:10.1371/journal.ppat.1007296

[41] Niu X, Kong F, Hou YJ, Wang Q. Crucial mutation in the exoribonuclease domain of nsp14 of PEDV leads to high genetic instability during viral replication. Cell Biosci. Jun 2021;11(1):106. doi:10.1186/s13578-02100598-1

[42] Kindler E, Gil-Cruz C, Spanier J, et al. Early endonuclease-mediated evasion of RNA sensing ensures efficient coronavirus replication. PLoS Pathog. 02 2017;13(2):e1006195. doi:10.1371/journal.ppat.1006195

[43] Stodola JK, Dubois G, Le Coupanec A, Desforges M, Talbot PJ. The OC43 human coronavirus envelope protein is critical for infectious virus production and propagation in neuronal cells and is a determinant of neurovirulence and CNS pathology. Virology. 02 2018;515:134-149. doi:10.1016/j.virol.2017.12.023

[44] Nakagawa K, Makino S. Mechanisms of Coronavirus Nsp1-Mediated Control of Host and Viral Gene Expression. Cells. $02 \quad$ 2021;10(2). doi:10.3390/cells10020300

[45] Vann KR, Tencer AH, Kutateladze TG. Inhibition of translation and immune responses by the virulence factor 
Nsp1 of SARS-CoV-2. Signal Transduct Target Ther. 10 2020;5(1):234. doi:10.1038/s41392-020-00350-0

[46] Angeletti S, Benvenuto D, Bianchi M, Giovanetti M, Pascarella S, Ciccozzi M. COVID-2019: The role of the nsp2 and nsp3 in its pathogenesis. J Med Virol. 06 2020;92(6):584-588. doi:10.1002/jmv.25719

[47] Gorkhali R, Koirala P, Rijal S, Mainali A, Baral A, Bhattarai HK. Structure and Function of Major SARSCoV-2 and SARS-CoV Proteins. Bioinform Biol Insights. 2021;15:11779322211025876. doi: $10.1177 / 11779322211025876$

[48] Oudshoorn D, Rijs K, Limpens RWAL, et al. Expression and Cleavage of Middle East Respiratory Syndrome Coronavirus nsp3-4 Polyprotein Induce the Formation of Double-Membrane Vesicles That Mimic Those Associated with Coronaviral RNA Replication. mBio. 11 2017;8(6). doi:10.1128/mBio.01658-17

[49] Angelini MM, Akhlaghpour M, Neuman BW, Buchmeier MJ. Severe acute respiratory syndrome coronavirus nonstructural proteins 3, 4, and 6 induce double-membrane vesicles. mBio. Aug 2013;4(4). doi:10.1128/mBio.00524-13

[50] Lei J, Kusov Y, Hilgenfeld R. Nsp3 of coronaviruses: Structures and functions of a large multi-domain protein. Antiviral Res. $01 \quad$ 2018;149:58-74. doi:10.1016/j.antiviral.2017.11.001

[51] Báez-Santos YM, St John SE, Mesecar AD. The SARScoronavirus papain-like protease: structure, function and inhibition by designed antiviral compounds. Antiviral Res. Mar 2015;115:21-38. doi:10.1016/j.antiviral.2014.12.015

[52] Sakai Y, Kawachi K, Terada Y, Omori H, Matsuura Y, Kamitani W. Two-amino acids change in the nsp4 of SARS coronavirus abolishes viral replication. Virology. 10 2017;510:165-174. doi:10.1016/j.virol.2017.07.019

[53] Kirchdoerfer RN, Ward AB. Structure of the SARS-CoV nsp12 polymerase bound to nsp7 and nsp8 co-factors. Nat Commun. 05 2019;10(1):2342. doi:10.1038/s41467019-10280-3

[54] te Velthuis AJ, Arnold JJ, Cameron CE, van den Worm $\mathrm{SH}$, Snijder EJ. The RNA polymerase activity of SARScoronavirus nsp12 is primer dependent. Nucleic Acids Res. Jan 2010;38(1):203-14. doi:10.1093/nar/gkp904

[55] Subissi L, Imbert I, Ferron F, et al. SARS-CoV ORF1bencoded nonstructural proteins 12-16: replicative enzymes as antiviral targets. Antiviral Res. Jan 2014;101:122-30. doi:10.1016/j.antiviral.2013.11.006

[56] Mirza MU, Froeyen M. Structural elucidation of SARSCoV-2 vital proteins: Computational methods reveal potential drug candidates against main protease, Nsp12 polymerase and Nsp13 helicase. J Pharm Anal. Aug 2020;10(4):320-328. doi:10.1016/j.jpha.2020.04.008

[57] Mickolajczyk KJ, Shelton PMM, Grasso M, et al. Forcedependent stimulation of RNA unwinding by SARSCoV-2 nsp13 helicase. Biophys J. 03 2021;120(6):10201030. doi:10.1016/j.bpj.2020.11.2276

[58] Deng X, Hackbart M, Mettelman RC, et al. Coronavirus nonstructural protein 15 mediates evasion of dsRNA sensors and limits apoptosis in macrophages. Proc Natl Acad Sci U S A. 05 2017;114(21):E4251-E4260. doi:10.1073/pnas.1618310114

[59] Liu X, Fang P, Fang L, et al. Porcine deltacoronavirus nsp15 antagonizes interferon- $\beta$ production independently of its endoribonuclease activity. Mol Immunol. 10 2019;114:100-107. doi:10.1016/j.molimm.2019.07.003

[60] Drosten C, Günther S, Preiser W, et al. Identification of a novel coronavirus in patients with severe acute respiratory syndrome. N Engl J Med. May 2003;348(20):1967-76. doi:10.1056/NEJMoa030747

[61] Seto WH, Tsang D, Yung RW, et al. Effectiveness of precautions against droplets and contact in prevention of nosocomial transmission of severe acute respiratory syndrome (SARS). Lancet. May 2003;361(9368):151920. doi:10.1016/s0140-6736(03)13168-6

[62] Zimmermann P, Curtis N. Coronavirus Infections in Children Including COVID-19: An Overview of the Epidemiology, Clinical Features, Diagnosis, Treatment and Prevention Options in Children. Pediatr Infect Dis J. 05 doi:10.1097/INF.0000000000002660

2020;39(5):355-368.

[63] Yip CC, Lam CS, Luk HK, et al. A six-year descriptive epidemiological study of human coronavirus infections in hospitalized patients in Hong Kong. Virol Sin. Feb 2016;31(1):41-8. doi:10.1007/s12250-016-3714-8

[64] Zaki AM, van Boheemen S, Bestebroer TM, Osterhaus $\mathrm{AD}$, Fouchier RA. Isolation of a novel coronavirus from a man with pneumonia in Saudi Arabia. N Engl J Med. Nov

2012;367(19):1814-20. doi:10.1056/NEJMoa1211721

[65] Jo WK, Drosten C, Drexler JF. The evolutionary dynamics of endemic human coronaviruses. Virus Evol. Jan 2021;7(1):veab020. doi:10.1093/ve/veab020

[66] Zhou P, Yang X-L, Wang X-G, et al. A pneumonia outbreak associated with a new coronavirus of probable bat origin. nature. 2020;579(7798):270-273. doi: 10.1038/s41586-020-2012-7.

[67] Shereen MA, Khan S, Kazmi A, Bashir N, Siddique R. COVID-19 infection: Origin, transmission, and characteristics of human coronaviruses. J Adv Res. Jul 2020;24:91-98. doi:10.1016/j.jare.2020.03.005

[68] Huang SH, Su MC, Tien N, et al. Epidemiology of human coronavirus NL63 infection among hospitalized patients with pneumonia in Taiwan. J Microbiol Immunol Infect. Dec 2017;50(6):763-770. doi:10.1016/j.jmii.2015.10.008

[69] Asghari A, Naseri M, Safari H, Saboory E, Parsamanesh N. The Novel Insight of SARS-CoV-2 Molecular Biology and Pathogenesis and Therapeutic Options. DNA Cell Biol. Oct 2020;39(10):1741-1753. doi:10.1089/dna.2020.5703

[70] Graepel KW, Lu X, Case JB, Sexton NR, Smith EC, Denison MR. Proofreading-Deficient Coronaviruses Adapt for Increased Fitness over Long-Term Passage without Reversion of Exoribonuclease-Inactivating Mutations. $\quad$ mBio. $\quad 11 \quad 2017 ; 8(6)$. doi:10.1128/mBio.01503-17

[71] Beidas M, Chehadeh W. PCR array profiling of antiviral genes in human embryonic kidney cells expressing human coronavirus OC43 structural and accessory proteins. Arch Virol. Aug 2018;163(8):2065-2072. doi:10.1007/s00705-018-3832-8

[72] Viswanathan T, Arya S, Chan SH, et al. Structural Basis of RNA Cap Modification by SARS-CoV-2 Coronavirus. bioRxiv. Apr 2020. doi:10.1101/2020.04.26.061705

[73] Sola I, Mateos-Gomez PA, Almazan F, Zuñiga S, Enjuanes L. RNA-RNA and RNA-protein interactions in 
coronavirus replication and transcription. RNA Biol. $2011 \quad$ Mar-Apr 2011;8(2):237-48. doi:10.4161/rna.8.2.14991

[74] Wu Z, Yang L, Ren X, et al. ORF8-Related Genetic Evidence for Chinese Horseshoe Bats as the Source of Human Severe Acute Respiratory Syndrome Coronavirus. J Infect Dis. Feb 2016;213(4):579-83. doi:10.1093/infdis/jiv476

[75] Uhler C, Shivashankar GV. Mechano-genomic regulation of coronaviruses and its interplay with ageing. Nat Rev Mol Cell Biol. 05 2020;21(5):247-248. doi:10.1038/s41580-020-0242-z

[76] Vishnubalaji R, Shaath H, Alajez NM. Protein Coding and Long Noncoding RNA (lncRNA) Transcriptional Landscape in SARS-CoV-2 Infected Bronchial Epithelial Cells Highlight a Role for Interferon and Inflammatory Response. Genes (Basel). $07 \quad$ 2020;11(7). doi:10.3390/genes11070760

[77] Cao Y, Li L, Feng Z, et al. Comparative genetic analysis of the novel coronavirus (2019-nCoV/SARS-CoV-2) receptor ACE2 in different populations. Cell Discov. 2020;6:11. doi:10.1038/s41421-020-0147-1

[78] Zella D, Giovanetti M, Cella E, et al. The importance of genomic analysis in cracking the coronavirus pandemic. Expert Rev Mol Diagn. Apr 2021:1-16. doi:10.1080/14737159.2021.1917998

[79] Sironi M, Hasnain SE, Rosenthal B, et al. SARS-CoV-2 and COVID-19: A genetic, epidemiological, and evolutionary perspective. Infect Genet Evol. Oct 2020;84:104384. doi:10.1016/j.meegid.2020.104384

[80] Kin N, Miszczak F, Diancourt L, et al. Comparative molecular epidemiology of two closely related coronaviruses, bovine coronavirus $(\mathrm{BCoV})$ and human coronavirus OC43 (HCoV-OC43), reveals a different evolutionary pattern. Infect Genet Evol. 06 2016;40:186191. doi:10.1016/j.meegid.2016.03.006

[81] Xiao J, Price J, Mina N. 1051: HUMAN CORONAVIRUS OC43-INDUCED ACUTE RESPIRATORY DISTRESS SYNDROME. Critical Care Medicine. 2018;46(1):509. doi:10.1097/01.ccm.0000529057.45150.a8

[82] Jevšnik Virant M, Černe D, Petrovec M, Paller T, Toplak I. Genetic Characterisation and Comparison of Three Human Coronaviruses (HKU1, OC43, 229E) from Patients and Bovine Coronavirus (BCoV) from Cattle with Respiratory Disease in Slovenia. Viruses. 04 2021;13(4). doi:10.3390/v13040676

[83] Edwards JK, Lessler J. What Now? Epidemiology in the Wake of a Pandemic. Am J Epidemiol. 01 2021;190(1):17-20. doi:10.1093/aje/kwaa159

[84] Attanayake AMCH, Perera SSN, Jayasinghe S. Phenomenological Modelling of COVID-19 Epidemics in Sri Lanka, Italy, the United States, and Hebei Province of China. Comput Math Methods Med. 2020;2020:6397063. doi:10.1155/2020/6397063

[85] Kin N, Miszczak F, Lin W, Gouilh MA, Vabret A, Consortium E. Genomic Analysis of 15 Human Coronaviruses OC43 (HCoV-OC43s) Circulating in France from 2001 to 2013 Reveals a High Intra-Specific Diversity with New Recombinant Genotypes. Viruses. May 2015;7(5):2358-77. doi:10.3390/v7052358

[86] Zobba R, Visco S, Sotgiu F, Pinna Parpaglia ML, Pittau M, Alberti A. Molecular survey of parvovirus, astrovirus, coronavirus, and calicivirus in symptomatic dogs. Vet Res Commun. Feb 2021;45(1):31-40. doi:10.1007/s11259-020-09785-w

[87] Jelinek HF, Mousa M, Alefishat E, et al. Evolution, Ecology, and Zoonotic Transmission of Betacoronaviruses: A Review. Front Vet Sci. 2021;8:644414. doi:10.3389/fvets.2021.644414

[88] Greenbaum U, Klein K, Martinez F, et al. High Levels of Common Cold Coronavirus Antibodies in Convalescent Plasma Are Associated With Improved Survival in COVID-19 Patients. Front Immunol. 2021;12:675679. doi:10.3389/fimmu.2021.675679

[89] Kandeel M, Ibrahim A, Fayez M, Al-Nazawi M. From SARS and MERS CoVs to SARS-CoV-2: Moving toward more biased codon usage in viral structural and nonstructural genes. J Med Virol. 06 2020;92(6):660666. doi:10.1002/jmv.25754

[90] Chan JF, Li KS, To KK, Cheng VC, Chen H, Yuen KY. Is the discovery of the novel human betacoronavirus $2 \mathrm{c}$ EMC/2012 (HCoV-EMC) the beginning of another SARS-like pandemic? J Infect. Dec 2012;65(6):477-89. doi:10.1016/j.jinf.2012.10.002

[91] Mutiawati E, Syahrul S, Fahriani M, et al. Global prevalence and pathogenesis of headache in COVID-19: A systematic review and meta-analysis. F1000Res. 2020;9:1316. doi:10.12688/f1000research.27334.2

[92] Ghandikota S, Sharma M, Jegga AG. Secondary analysis of transcriptomes of SARS-CoV-2 infection models to characterize COVID-19. Patterns (N Y). May 2021;2(5):100247. doi:10.1016/j.patter.2021.100247

[93] Viehweger A, Krautwurst S, Lamkiewicz K, et al. Direct RNA nanopore sequencing of full-length coronavirus genomes provides novel insights into structural variants and enables modification analysis. Genome Res. 09 2019;29(9):1545-1554. doi:10.1101/gr.247064.118

[94] Li J, Li Z, Cui X, Wu C. Bayesian phylodynamic inference on the temporal evolution and global transmission of SARS-CoV-2. J Infect. 08 2020;81(2):318-356. doi:10.1016/j.jinf.2020.04.016

[95] Kiyuka PK, Agoti CN, Munywoki PK, et al. Human Coronavirus NL63 Molecular Epidemiology and Evolutionary Patterns in Rural Coastal Kenya. J Infect Dis. $\quad 05 \quad 2018 ; 217(11): 1728-1739$. doi:10.1093/infdis/jiy098

[96] Yuan Y, Cao D, Zhang Y, et al. Cryo-EM structures of MERS-CoV and SARS-CoV spike glycoproteins reveal the dynamic receptor binding domains. Nat Commun. 04 2017;8:15092. doi:10.1038/ncomms 15092

[97] Gupta A, Kumar S, Kumar R, et al. COVID-19: Emergence of Infectious Diseases, Nanotechnology Aspects, Challenges, and Future Perspectives. ChemistrySelect. Jul 2020;5(25):7521-7533. doi:10.1002/slct.202001709

[98] Daniloski Z, Jordan TX, Wessels HH, et al. Identification of Required Host Factors for SARS-CoV-2 Infection in Human Cells. Cell. 01 2021;184(1):92-105.e16. doi:10.1016/j.cell.2020.10.030

[99] Gautam A, Kaphle K, Shrestha B, Phuyal S. Susceptibility to SARS, MERS, and COVID-19 from animal health perspective. Open Vet J. 08 2020;10(2):164-177. doi:10.4314/ovj.v10i2.6

[100] Khan MT, Ali S, Khan AS, et al. SARS-CoV-2 Genome from the Khyber Pakhtunkhwa Province of Pakistan. 
ACS Omega. Mar 2021;6(10):6588-6599. doi:10.1021/acsomega.0c05163

[101] DeDiego ML, Nieto-Torres JL, Jimenez-Guardeño JM, et al. Coronavirus virulence genes with main focus on SARS-CoV envelope gene. Virus Res. Dec 2014;194:124-37. doi:10.1016/j.virusres.2014.07.024

[102] Standl F, Jöckel KH, Brune B, Schmidt B, Stang A. Comparing SARS-CoV-2 with SARS-CoV and influenza pandemics. Lancet Infect Dis. 04 2021;21(4):e77. doi:10.1016/S1473-3099(20)30648-4

[103] Forni D, Cagliani R, Clerici M, Sironi M. Molecular Evolution of Human Coronavirus Genomes. Trends Microbiol. $\quad 01 \quad 2017 ; 25(1): 35-48$. doi:10.1016/j.tim.2016.09.001

[104] Huang X, Dong W, Milewska A, et al. Human Coronavirus HKU1 Spike Protein Uses O-Acetylated Sialic Acid as an Attachment Receptor Determinant and Employs Hemagglutinin-Esterase Protein as a ReceptorDestroying Enzyme. J Virol. Jul 2015;89(14):7202-13. doi:10.1128/JVI.00854-15

[105] Martínez-Álvarez F, Asencio-Cortés G, Torres JF, et al. Coronavirus Optimization Algorithm: A Bioinspired Metaheuristic Based on the COVID-19 Propagation Model. Big Data. 08 2020;8(4):308-322. doi:10.1089/big.2020.0051

[106] Dubé M, Le Coupanec A, Wong AHM, Rini JM, Desforges M, Talbot PJ. Axonal Transport Enables Neuron-to-Neuron Propagation of Human Coronavirus OC43. J Virol. 09 2018;92(17). doi:10.1128/JVI.0040418

[107] Szczepanski A, Owczarek K, Bzowska M, et al. Canine Respiratory Coronavirus, Bovine Coronavirus, and Human Coronavirus OC43: Receptors and Attachment Factors. Viruses. 04 2019;11(4). doi:10.3390/v11040328

[108] Kim T, Choi H, Shin TR, et al. Epidemiology and clinical features of common community human coronavirus disease. J Thorac Dis. Apr 2021;13(4):22882299. doi:10.21037/jtd-20-3190

[109] Sajjad H, Majeed M, Imtiaz S, et al. Origin, Pathogenesis, Diagnosis and Treatment Options for SARS-CoV-2: A Review. Biologia (Bratisl). Jun 2021:119. doi:10.1007/s11756-021-00792-Z

[110] Zhang SF, Tuo JL, Huang XB, et al. Epidemiology characteristics of human coronaviruses in patients with respiratory infection symptoms and phylogenetic analysis of HCoV-OC43 during 2010-2015 in

Guangzhou. PLoS One. 2018;13(1):e0191789. doi:10.1371/journal.pone.0191789

[111] Morawska L, Cao J. Airborne transmission of SARSCoV-2: The world should face the reality. Environ Int. 06 2020;139:105730. doi:10.1016/j.envint.2020.105730

[112] Zu ZY, Jiang MD, Xu PP, et al. Coronavirus Disease 2019 (COVID-19): A Perspective from China. Radiology. $\quad 08 \quad$ 2020;296(2):E15-E25. doi:10.1148/radiol.2020200490

[113] Jee Y. WHO International Health Regulations Emergency Committee for the COVID-19 outbreak. Epidemiol Health. 2020;42: e2020013. doi:10.4178/epih.e2020013

[114] Shereen MA, Khan S, Kazmi A, Bashir N, Siddique R. COVID-19 infection: Origin, transmission, and characteristics of human coronaviruses. Journal of advanced research. 2020;24:91-98. doi: 10.1016/j.jare.2020.03.005.

[115] Briguglio M, Pregliasco FE, Lombardi G, Perazzo P, Banfi G. The Malnutritional Status of the Host as a Virulence Factor for New Coronavirus SARS-CoV-2. Front Med (Lausanne). 2020;7: 146. doi:10.3389/fmed.2020.00146

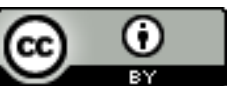

Open Access This article is licensed under a Creative Commons Attribution 4.0 International License, which permits use, sharing, adaptation, distribution and reproduction in any medium or format, as long as you give appropriate credit to the original author(s) and the source, provide a link to the Creative Commons license, and indicate if changes were made. The images or other third party material in this article are included in the article's Creative Commons license, unless indicated otherwise in a credit line to the material. If material is not included in the article's Creative Commons license and your intended use is not permitted by statutory regulation or exceeds the permitted use, you will need to obtain permission directly from the copyright holder. To view a copy of this license, visit https://creativecommons.org/licenses/by/4.0/.

(c) The Author(s) 2021 